\title{
Biophysical characteristics of a morphologically-complex macrotidal tropical coastal system during a dry season
}

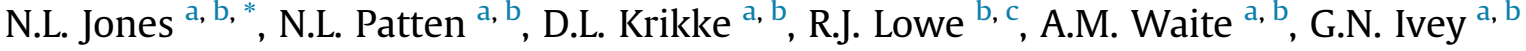 \\ a School of Civil, Environmental and Mining Engineering, The University of Western Australia, Australia \\ ${ }^{\mathrm{b}}$ UWA Oceans Institute, Australia \\ ${ }^{\mathrm{c}}$ School of Earth and Environment, The University of Western Australia, Australia
}

\section{A R T I C L E I N F O}

\section{Article history:}

Received 9 January 2014

Accepted 27 July 2014

Available online 5 August 2014

\section{Keywords:}

coastal oceanography

oceanic front

phytoplankton

marine food webs

Regional index terms:

Kimberley

Western Australia

Southeastern Indian Ocean

\begin{abstract}
A B S T R A C T
Four boat-based surveys and several moored measurements were conducted over the dry season in June, July, August and September 2008 in the central Kimberley region of northwestern Australia; a macrotidal tropical coastal region, characterised by numerous island archipelagos and shallow reefs. The objective was to determine the influence of this complex morphology on the biophysical properties of the local coastal water masses and the resultant impact on phytoplankton biomass. Despite negligible rainfall during the dry-season, decreased salinity towards the coast suggested a persistent fresh water source. The water column was weakly vertically-stratified throughout much of the study region, only becoming well-mixed in topographically constricted regions. The vertical stratification resulted in a cross-shore subsurface in situ chl- $a$ fluorescence maxima (at $~ 30 \mathrm{~m}$ depth) in June, July and August. The presence of a chain of islands and shallow reefs led to the partial isolation of the semi-enclosed embayment, Collier Bay, creating distinct water masses across this relatively small area. The confluence of the two most distinct water masses formed a front at latitude $15.65-15.7^{\circ} \mathrm{S}$, in both June and August, indicating it was a persistent feature during the dry season. In situ chl- $a$ fluorescence was highest at the front location. In Collier Bay, $\mathrm{NO}_{\mathrm{x}}$ concentrations were up to five times higher, with a $20 \%$ higher proportion of larger extracted chl- $a$ biomass (cells $>5 \mu \mathrm{m}$ ), a proxy for phytoplankton. In the more open waters of Camden Sound, relatively high concentrations of picophytoplankton, bacteria and viruses were observed. Such spatial shifts in nutrient concentrations, phytoplankton biomass and phytoplankton and microbial community composition across the persistent density front are likely to have important consequences on the region's planktonic food web function.
\end{abstract}

() 2014 Elsevier Ltd. All rights reserved.

\section{Introduction}

The complex morphology associated with island archipelagos, reefs, capes and headlands can play an important role in determining the ecological function of coastal waters. Regions inshore of reef and island matrices are isolated by varying degrees from adjoining offshore oceanic waters, potentially leading to localised physical and biogeochemical processes that can have a large influence on the local biological response (e.g., Furnas et al., 2005; Wyatt et al., 2012). Furthermore, the interaction of currents with island archipelagos and coastal headlands can create distinct frontal zones with converging and diverging flows, thereby

\footnotetext{
* Corresponding author. School of Civil, Environmental and Mining Engineering, The University of Western Australia, M015 35 Stirling Highway, Crawley, WA 6009, Australia.

E-mail address: nicole.jones@uwa.edu.au (N.L. Jones).
}

influencing the distribution of sediment, phytoplankton and weakswimming nekton (e.g., Johnston and Read, 2007). The combined effect of these processes can lead to large variations in the function of planktonic ecosystems over small spatial areas.

Islands and reefs can reduce the exchange of shallow coastal waters with the offshore deeper ocean. For example, the extensive offshore reef and island matrix of the Great Barrier Reef (GBR), Australia hinders the cross-shelf exchange of water, in turn, leading to a relatively high residence time of coastal water within the GBR lagoon (e.g., Wolanski and Spagnol, 2000; Brinkman et al., 2002; Andutta et al., 2013). Intense recycling of nutrients is then required to sustain coastal water column productivity (Alongi and McKinnon, 2005; McKinnon et al., 2013). Another example is Kaneohe Bay, Hawaii, where the limited exchange with offshore water due the barrier reef leads to the stimulation of phytoplankton growth within the Bay, driven by episodic inputs of terrestriallyderived nutrients from storm water runoff (Drupp et al., 2011). 
In coastal areas with complex morphology, partial isolation of water masses through restricted exchange can lead to the creation of physically distinct water masses separated by a frontal zone (i.e., characterised by strong horizontal temperature and/or salinity differences) (Franks, 1992a; O'Donnell, 1993). Alternatively, features such as headlands or islands can also create fronts, characterised by locally well-mixed regions that contrast with the adjacent vertically stratified water column (O'Donnell, 2010). These frontal zones often contain high phytoplankton biomass due to either 1) passive convergent transport toward the front or 2) in situ production within the front itself driven by the establishment of optimal light and locally-enhanced nutrient supply conditions (Franks, 1992a,b; Li et al., 2007). Furthermore, the trophic structure of marine food webs can shift from one side of a front to the other: tending towards a herbivorous food chain (large phytoplankton to zooplankton to fish) (Ryther, 1969) on the nutrient-rich, wellmixed side of the front, and a nutrient recycling microbial loop food web (comprising bacteria, picoplankton, nanoplankton and viruses) (Azam et al., 1983; Fuhrman, 1992), occurring in the oligotrophic waters in the adjacent vertically-stratified ocean (e.g., Rodríguez et al., 2000; Fu et al., 2009).

The tropical central coast of the Kimberley in northwestern Australia contains an extensive system of islands and reefs that interact with its extreme tides (Fig. 1). This region has a broad continental shelf ( $200 \mathrm{~km}$ in width) with a morphologically complex coastal region, where drowned river valleys have formed deep and narrow inlets, and isolated ridges have evolved into extensive island archipelagos (Masini et al., 2009). The tides are semidiurnal, with tidal ranges among the highest in the world; spring tides reach up to $11 \mathrm{~m}$ and result in current speeds in excess of $2 \mathrm{~m} \mathrm{~s}^{-1}$ (Anon, 1972). Combined with this region's tropical monsoonal climate, these unique conditions have produced a very ecologically diverse marine ecosystem, with marine communities including coral reefs, seagrass meadows, mangrove forests and sponge gardens. These communities provide habitat, shelter and food resources for culturally and commercially important species, including marine turtles, cetaceans, dugongs, fish, prawns and birds (Masini et al., 2009). Despite the importance of the region, remarkably little is known about its oceanography.

Below we describe results from a 4-month field study of the oceanography of the central Kimberley coast which, for the first time, quantifies the physical, chemical and biological properties of this unstudied coastal region during a dry season. Specifically, we utilise a combination of moored and ship-based measurements to determine: (1) the intra-seasonal variation in physical water properties, (2) the spatial variation in physico-chemical and biological parameters and (3) the influence of the complex morphology on the water mass properties, as well as the resultant impact on the planktonic ecosystem.

\section{Methods}

\subsection{Study site}

The study was conducted in two large bays, Camden Sound and Collier Bay, in the central Kimberley region (Fig. 1) within the southeast Indian Ocean. Camden Sound has an average depth of $30 \mathrm{~m}$ and is reasonably open to the offshore shelf ocean. In contrast, Collier Bay is encircled by a series of islands and reefs, including the extensive Montgomery Reef, and has an average depth of just $10 \mathrm{~m}$. The total catchment area that discharges into Collier Bay, predominantly through Walcott Inlet, is $\sim 20,000 \mathrm{~km}^{2}$ compared with just $\sim 500 \mathrm{~km}^{2}$ into Camden Sound (http://www.ozcoasts.gov.au).

The region experiences a tropical monsoonal climate, with distinct dry (May to October) and wet (November to April) seasons. In the dry season, the average rainfall is only $~ 5 \%$ of the total annual rainfall (averaging $1449 \mathrm{~mm}^{-1} \mathrm{ear}^{-1}$ ) and air temperatures are also at their coolest (1962-2010 climate statistics from Kuri Bay meteorological station, http://www.bom.gov.au). The regional wind patterns in the eastern Indian Ocean are determined by the monsoon cycle. In April, the southeasterly trade winds become well-established, bringing dry continental air over the ocean, eventually dominating the region from May to September (Tomczak and Godfrey, 2003).

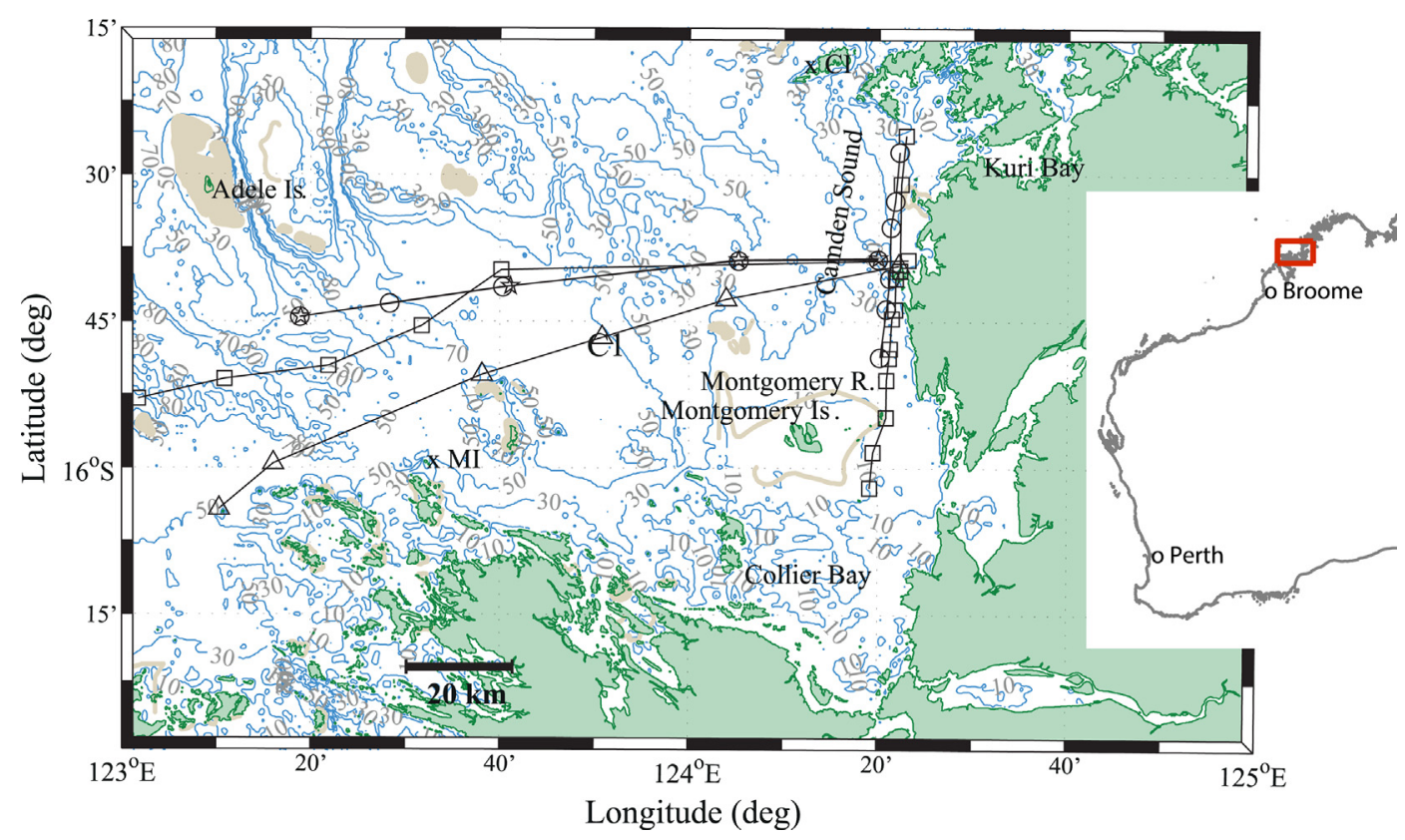

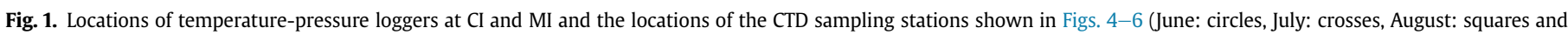

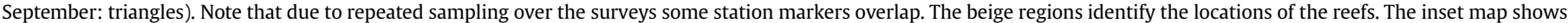

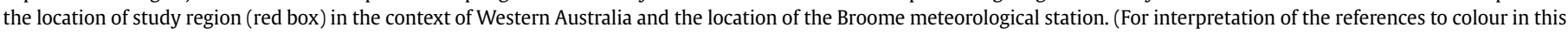
figure legend, the reader is referred to the web version of this article.) 


\subsection{Measurements}

During a dry season (June-Sept 2008), measurements of physical, chemical and biological parameters of the water column were made during four approximately week-long surveys. Ship-based transects were conducted in "June" (27 June-2 July), "July" (31 July-4 August), "August" (25-29 August) and "September" (17-22 September) (Table 1). The sampling strategy varied somewhat for each survey as early data from the study focussed our efforts. During each survey, conductivity-temperature-depth (CTD, SBE19plus, Seabird Electronics) water column profiles were taken at a number of stations, many of which were repeated during the four surveys (Table 1, Fig. 1). In addition, profiles of turbidity (AQUAtracka Nephelometer, Chelsea Technologies Group) and chlorophyll a fluorescence (AQUAtracka Fluorometer, Chelsea Technologies Group) were measured during the June, July and August surveys (Table 1, Fig. 1). The turbidity sensor was not calibrated specifically for this study, therefore the data is reported as a relative unit in volts.

Two bottom-mounted temperature-pressure loggers, which sampled at $30 \mathrm{~s}$ intervals (SBE39, Seabird Electronics), were deployed from 27 June to 26 August near Champagney Island (CI) and MacIntyre Island (MI) (Fig. 1). We obtained regional weather data from the Bureau of Meteorology at three stations, which included wind speed, air temperature and atmospheric pressure at Adele Island, located $100 \mathrm{~km}$ to the west; relative humidity from Broome, located $\sim 310 \mathrm{~km}$ to the southwest; and rainfall from Kuri Bay, located $40 \mathrm{~km}$ to the northeast (Fig. 1). The wind speed and relative humidity data is valid over large spatial regions in the dry season of the West Kimberley due to the large-scale synoptic weather patterns that influence the region at this time of the year (Tomczak and Godfrey, 2003). In addition, 6 h estimates of shortwave radiation and cloud cover at $\sim 2^{\circ}$ spatial resolution were obtained from the National Oceanic \& Atmospheric Administration, National Center for Environmental Prediction (NCEP) Reanalysis data (http://www.cdc.noaa.gov) (Kalnay et al., 1996), as this data was not available from the meteorological stations.

During the June and August surveys, surface seawater was sampled at each station and analysed for chlorophyll $a$ (chl- $a$ ); a proxy for phytoplankton biomass, and dissolved inorganic nutrients $\left(\left(\mathrm{NO}_{\mathrm{x}}\left(\mathrm{NO}_{2}+\mathrm{NO}_{3}\right), \mathrm{NH}_{4}, \mathrm{PO}_{4}\right.\right.$, and $\left.\mathrm{Si}\right)$ (Table 1$)$. Seawater was processed for two size fractions of chl- $a$; total chl- $a$ and and chl- $a>$ $5 \mu \mathrm{m}$. For total chl- $a$, replicate seawater samples ( $1 \mathrm{~L}$ ) were filtered onto $25 \mathrm{~mm}$ glass fibre filters (GF/F, Whatman; $0.7 \mu \mathrm{m}$ nominal pore size). For chl- $a>5 \mu \mathrm{m}$ (herein termed 'large phytoplankton'), replicate seawater samples $(2 \mathrm{~L}$ ) were filtered onto $25 \mathrm{~mm}$ discs of $\sim 5 \mathrm{~m}$ mesh. All filters were stored frozen in the dark until extraction and analysis. Chl- $a$ concentrations were determined fluorometrically in the laboratory using a Turner Designs (TD700) fluorometer. The fraction of chl- $a<5 \mu \mathrm{m}$ (herein termed 'small phytoplankton') was calculated by subtracting chl- $a>5 \mu \mathrm{m}$ from total chl- $a$. In addition, a subset of mid-water column seawater
( $n=18$ ) was also processed for total chl- $a$ and used together with surface total chl- $a(n=90)$ in order to calibrate the chl- $a$ fluorescence profile data (termed in situ chl-a fluorescence hereafter) $\left(R^{2}=0.74\right)$. Samples for dissolved nutrients $\left(\mathrm{NO}_{\mathrm{x}}\left(=\mathrm{NO}_{2}+\mathrm{NO}_{3}\right)\right.$, $\mathrm{NH}_{4}, \mathrm{PO}_{4}$, and $\left.\mathrm{Si}\right)$ were syringe filtered $(0.45 \mu \mathrm{m}$, Supor, Acrodisc) and frozen, with their concentrations later analysed on a Lachat QuikChem 8000 Flow Injection Analyser. Detection limits were approximately $0.1 \mu \mathrm{mol} \mathrm{L}-1$ for $\mathrm{NO}_{\mathrm{x}}\left(\mathrm{NO}_{3}\right.$ and $\left.\mathrm{NO}_{2}\right), \mathrm{PO}_{4}$ and $\mathrm{Si}$ and $0.2 \mu \mathrm{mol} \mathrm{L}^{-1}$ for $\mathrm{NH}_{4}$.

In August, the community composition of the small phytoplankton and microbes was investigated further and we found the $<5 \mu \mathrm{m}$ fraction of chl- $a$ dominated the biomass in the June survey. Specifically, surface seawater was sampled for autotrophic picoplankton (picophytoplankton; cells $0.2-\sim 2-3 \mu \mathrm{m}$ in size), bacteria (inclusive of both bacteria and Archaea; 'bacteria' herein) and viruses (Table 1). Duplicate seawater samples $(1.5 \mathrm{~mL})$ were fixed in electron microscopy grade glutaraldehyde $(0.5 \%$ final concentration) in the dark for $15 \mathrm{~min}$; the samples were then quick-frozen in liquid nitrogen until analysis (Marie et al., 1999).

For picophytoplankton analysis, samples were thawed at $37^{\circ} \mathrm{C}$, $1 \mu \mathrm{m}$ fluorescent beads (Molecular Probes) were added as an internal standard and analysed using a FACSCANTO II (Becton Dickinson) flow cytometer fitted with a $488 \mathrm{~nm}$ laser on high throughput mode at a flow rate of $60 \mu \mathrm{L} \mathrm{min}^{-1}$ for $2 \mathrm{~min}$. Different picophytoplankton groups were discriminated on the basis of red and orange autofluorescence of chlorophyll and the accessory pigment phycoerythrin (Marie et al., 1999). Samples for bacteria and viruses were thawed at $37{ }^{\circ} \mathrm{C}$, diluted five-fold in $0.02 \mu \mathrm{m}$ filtered Tris EDTA buffer ( $\mathrm{pH} 8$, Sigma-Aldrich), stained with SYBR I Green $\left(0.5 \times 10^{-4}\right.$ final concentration $)$ in the dark at $80^{\circ} \mathrm{C}$, and then $0.75 \mu \mathrm{m}$ fluorescent beads (Molecular Probes) were added as an internal standard (Brussaard, 2004). Bacteria and viruses were analysed using the same flow cytometer, with a flow rate of $30 \mu \mathrm{L} \mathrm{min}^{-1}$ for $2 \mathrm{~min}$. Virus counts were corrected against a blank consisting of $0.02 \mu \mathrm{m}$ filtered TE buffer with $0.02 \mu \mathrm{m}$ filtered (5:1) seawater. Bacteria and viruses were discriminated based on side scatter and green (SYBR I) fluorescence.

Picophytoplankton cell abundances were converted to carbon biomass using conversion values of $154 \mathrm{fg} \mathrm{C}$ cell $^{-1}$ and $1319 \mathrm{fg} \mathrm{C}$ cell $^{-1}$ for Synechococcus and picoeukaryotes, respectively (Buitenhuis et al., 2012).

\subsection{Data analysis}

The CTD stations were grouped together to produce a number of cross-sections that captured key spatial features of the ocean properties. The cross-sections were comprised of observations that were all collected within an $8 \mathrm{~h}$ period. Based on the typical tidal velocity amplitude in the Camden Sound/Collier Bay region $\left(U_{0} \sim 1 \mathrm{~m} \mathrm{~s}^{-1}\right)$ and tidal period for the dominant $\mathrm{M}_{2}$ tidal constituent $T=12.42 \mathrm{~h}$, the tidal excursion length was $L_{\mathrm{TE}}=U_{0} T / \pi \sim 10 \mathrm{~km}$. Due to the short tidal excursion relative to the total cross-section

Table 1

Summary of survey dates, tidal range and physico-chemical and biological parameters measured during each survey.

\begin{tabular}{|c|c|c|c|c|c|c|c|}
\hline \multirow[t]{2}{*}{ Survey } & \multirow{2}{*}{$\begin{array}{l}\text { Mean tidal range } \\
(\min -\max )[\mathrm{m}]\end{array}$} & \multicolumn{6}{|c|}{ Number of stations where parameter measured } \\
\hline & & CTD & $\begin{array}{l}\text { CTD } \\
\text { with FT }\end{array}$ & $\begin{array}{l}\text { Total } \\
\text { chl- } a\end{array}$ & $\begin{array}{l}\text { chl- } a \\
>5 \mu \mathrm{m}\end{array}$ & Nutrients & Pico/Bac/Vir \\
\hline June (27 June-2 July) & $4.7(2.9-7.6)$ & 52 & 52 & 52 & 46 & 19 & $\mathrm{NS}^{\mathrm{b}}$ \\
\hline August (25-29 August) & $3.5(1.1-6.2)$ & 56 & 56 & 56 & 56 & 56 & 55 \\
\hline $\begin{array}{l}\text { September } \\
\quad(17-22 \text { September })\end{array}$ & $8.6(4.6-10.3)$ & 47 & NS & NS & NS & NS & NS \\
\hline
\end{tabular}

a Indicates CTD with chl- $a$ fluorometer and turbidity sensors.

b Indicates parameters not sampled. 
lengths (the shortest distance is $\sim 60 \mathrm{~km}$ ), the cross-sections can thus be treated as stationary representation of the ocean conditions.

We calculated the hourly surface net heat flux in the region by summing the different individual heat flux components. The 6-h NCEP reanalysis short-wave radiation product was interpolated to 1 -h values by fitting a second order polynomial to the available day time data and assuming the short-wave radiation was zero from sunset to sunrise. Long-wave radiation was calculated using the Berliand bulk formula from the observed near-bed (average water depth of $18.8 \mathrm{~m}$ ) water temperature at Champagney Island $(\mathrm{CI})$, the air temperature and relative humidity from the weather stations, and the cloudiness correction factor from the NCEP reanalysis (Fung et al., 1984). We calculated the latent and sensible heat flux following Fairall et al., (1996) using the CI near-bed water temperature, and the observed wind speed, air temperature, atmospheric pressure and the relative humidity. We applied a low-pass 48-h third-order Butterworth filter to the raw heat-flux data to remove diurnal fluctuations and the near-bed water temperature to remove both tidal and diurnal fluctuations.

Pearson correlation coefficients $r$ were computed between the picophytoplankton, bacteria and viruses and both the physicochemical and biological data (all data were log transformed) using SPSS (version 19). Dissolved nutrient concentrations below detection limits were not included in the calculations.

\section{Results}

\subsection{Meteorological and tidal conditions}

During our study in the dry season, the total rainfall was just $1 \%$ $(82 \mathrm{~mm})$ of the annual rainfall $(1936 \mathrm{~mm})$ and air temperatures during this time were the coolest of the year (Fig. 2). Rainfall in the previous 2007/2008 wet season was higher than average (Fig. 2). The winds prevailed predominantly from the southeast and were highly variable in speed, with a moderate daily sea-breeze component (not shown). Three strong wind events occurred during the study period, with wind speeds reaching up to $40 \mathrm{~km} \mathrm{~h}^{-1}$ (equivalent to a wind stress of $\sim 0.1 \mathrm{~N} \mathrm{~m}^{-2}$ ), each persisting for several days (Fig. 3b). These strong easterly wind events were associated with low relative humidity (Fig. 3b).

The semidiurnal tides resulted in a variety of tidal conditions experienced during each survey. Neap tide conditions characterised

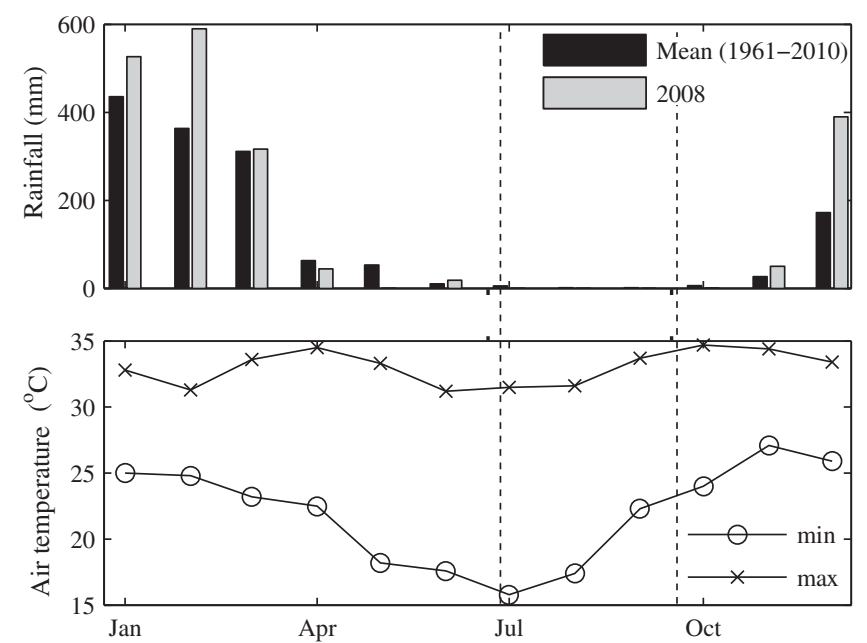

Fig. 2. Kuri Bay meteorological station: (a) 45-year mean (1961-2010) and 2008 monthly rainfall data and (b) monthly-mean minimum (circle) and maximum (crosses) air temperature in 2008 . The dashed lines delineate the study period. the June and August surveys, whereas the July and September surveys occurred during spring tide conditions (Table 1 ).

\subsection{Temporal variation in temperature, salinity and density}

Seasonal cooling of the water occurred in Camden Sound from July to mid-September (Fig. 3). On three occasions during this period, the near-bed temperature decreased rapidly (on the order of $1{ }^{\circ} \mathrm{C}$ within days, Fig. 3a). The three cooling events coincided with strong winds (prevailing from the southeast) and low relative humidity, leading to large latent heat losses (Fig. 3). Whilst the net surface heat fluxes explained most of the variability in water temperature in Camden Sound, it is also possible that water masses of different temperature were occasionally advected into the region.

Cooler inshore water temperatures were observed from June to August: the depth-averaged water temperature $\bar{T}$ was $1{ }^{\circ} \mathrm{C}$ cooler inshore ( $\sim 30 \mathrm{~m}$ depth) relative to $\sim 100 \mathrm{~km}$ offshore ( $\sim 70 \mathrm{~m}$ depth) (Fig. 4a). Conversely, in September when there was a net heat flux into the water column, the inshore $\bar{T}$ increased by $\sim 1{ }^{\circ} \mathrm{C}$ compared with the offshore water. From June to September, the water became increasingly saline, with the nearshore depth-averaged salinity $\bar{S}$ increasing from 34.2 to 34.9 over this period (Fig. 4b). The weak cross-shore salinity gradient observed in June further weakened until by September the salinity was nearly spatially-uniform.

The opposing cross-shore $\bar{T}$ and $\bar{S}$ gradients resulted in nearuniform cross-shore depth-averaged densities $\bar{\rho}$ from June to August (Fig. 4c). In June, $\bar{\rho}$ was at a minimum $31 \mathrm{~km}$ off the coast due to the temperature controlling the density adjacent to the coast (Fig. 4c). The cross-shore $\bar{\rho}$ gradient was strengthened by the now shoreward increasing $\bar{T}$ in September, resulting in a cross-shore density change of $1 \mathrm{~kg} \mathrm{~m}^{-3}$ (Fig. 4c).

\subsection{Vertical structure of density}

Despite the large tidal range in this region and the minimal freshwater input in the dry season (Table 1), the water column was vertically stratified over large portions of the study region (e.g., Fig. 5a). The water column was generally weakly verticallystratified in the shallow regions (close to the coast) with the stratification increasing in the deeper offshore waters (Fig. 5a). Vertical stratification was weaker during the July and September surveys when the tidal range was largest (Table 1), possibly resulting from increased tidal mixing.

In the alongshore direction, the cooler coastal water was vertically well-mixed in the narrow channel between Montgomery Reef and the mainland to the east, relative to the warmer and verticallystratified water to the north in Camden Sound (Fig. 6a and c). The confluence of these two different water masses formed a density front at latitude $\sim 15.65-15.7{ }^{\circ} \mathrm{S}$ during both the June and August surveys (Fig. 6a and c); coastal alongshore transects were not conducted during the July and September surveys.

\subsection{Turbidity}

Highest turbidity occurred close to the seabed, particularly in shallower water (e.g., Fig. 5b). However, a surface turbidity maximum was also present in June at water depths $<40 \mathrm{~m}$ (not shown). Higher turbidity values occurred in Collier Bay, contrasting with the much less turbid water in the north of Camden Sound (not shown).

\subsection{Nutrients}

Surface dissolved inorganic nutrient concentrations during the June and August surveys are summarised in Table 2. At many stations in June and August, $\mathrm{NO}_{\mathrm{x}}$ was near or below the detection limit 
a)

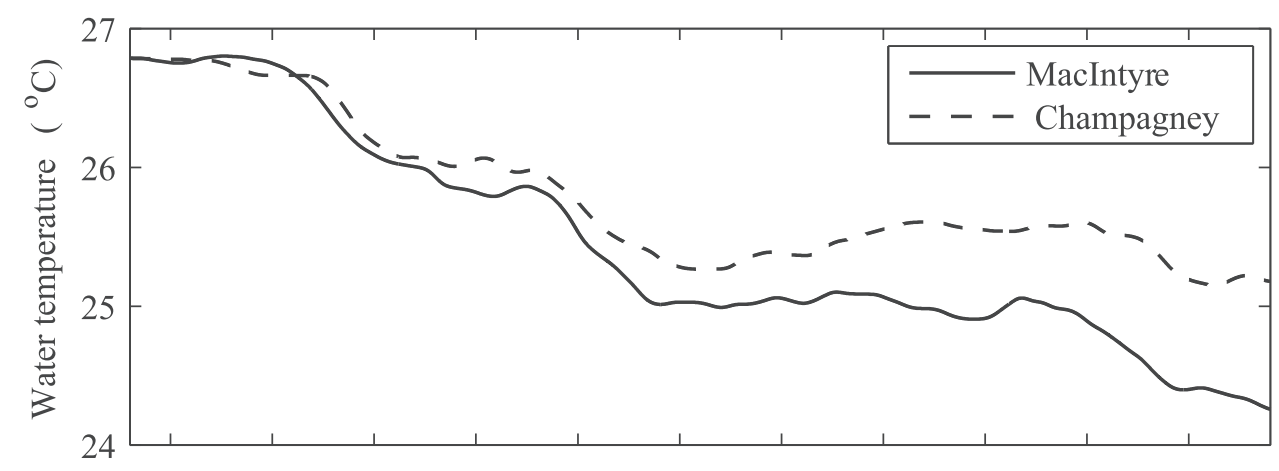

b)
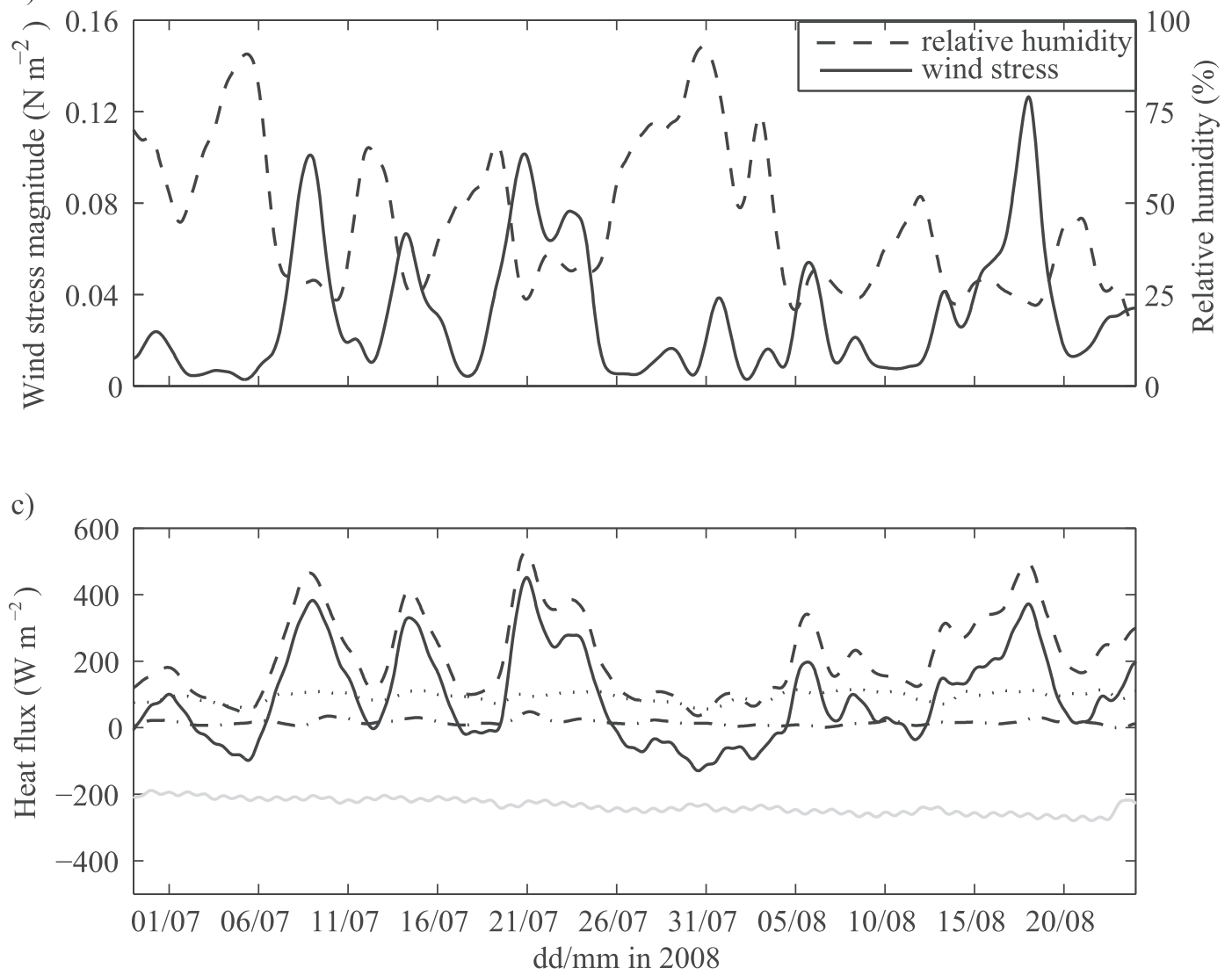

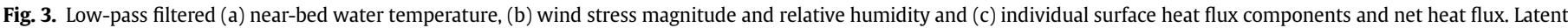

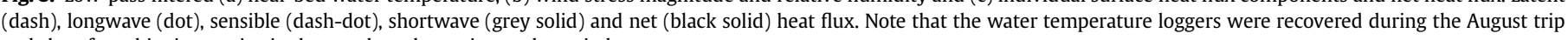
and therefore this time series is shorter than the entire study period.

(Table 2 and Fig. 7a and e). However, higher $\mathrm{NO}_{\mathrm{x}}$ concentrations, measuring up to $0.5 \mu \mathrm{mol} \mathrm{L} \mathrm{L}^{-1}$ occurred within Collier Bay, were concomitant with the lowest $\mathrm{NH}_{4}$ concentrations (for June see $7 \mathrm{a}$ and $\mathrm{b}$ and for August see Fig. 7e and f). Conversely, the highest $\mathrm{NH}_{4}$ concentrations (i.e., up to $1.3 \mu \mathrm{mol} \mathrm{L}{ }^{-1}$ ) occurred at the Camden Sound stations (Fig. 7a, b, e and f). There was thus a shift from overall low but detectable $\mathrm{NO}_{\mathrm{x}}$ concentrations closer to the coast to $\mathrm{NO}_{\mathrm{x}}$ concentrations which were near and or below detection limit; this transition thus occurred near the location of the density front in August at latitude $15.7^{\circ} \mathrm{S}$; (Fig. 7e). The sparser nutrient sampling in June did not reveal significant differences north and south of the front (Fig. 7a). The trend was less distinct across the density front for $\mathrm{NH}_{4}$ but overall low but detectable $\mathrm{NH}_{4}$ concentrations occurred in the water north of the density front in August (Fig. 7f). Spatial patterns in $\mathrm{PO}_{4}$ were less clear than for $\mathrm{NO}_{\mathrm{x}}$ and $\mathrm{NH}_{4}$; however, generally lower $\mathrm{PO}_{4}$ concentrations occurred at stations situated in deeper water offshore (i.e., $>50 \mathrm{~m}$ ) (Fig. $7 \mathrm{c}$ and g). Si concentrations varied 7 -fold with highest concentrations occurring adjacent to the coast and within Collier Bay (Fig. 7d and h).

\subsection{Chlorophyll a}

Surface chl- $a$ concentrations for the June and August surveys are summarised in Table 2. On average, $87 \%$ and $85 \%$ of the chl- $a$ biomass occurred in the $<5 \mu \mathrm{m}$ size fraction in the June and August surveys, respectively (Fig. 8b). In August, the highest surface chl- $a$ 
a)

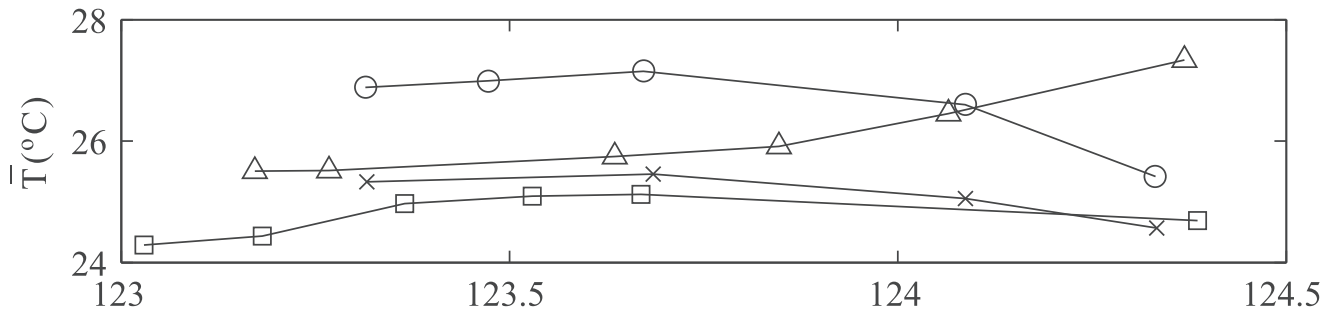

b)

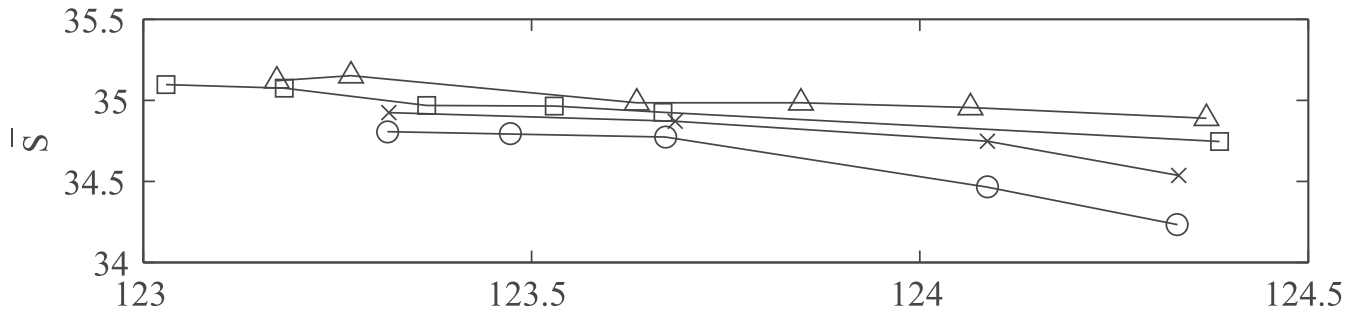

c)

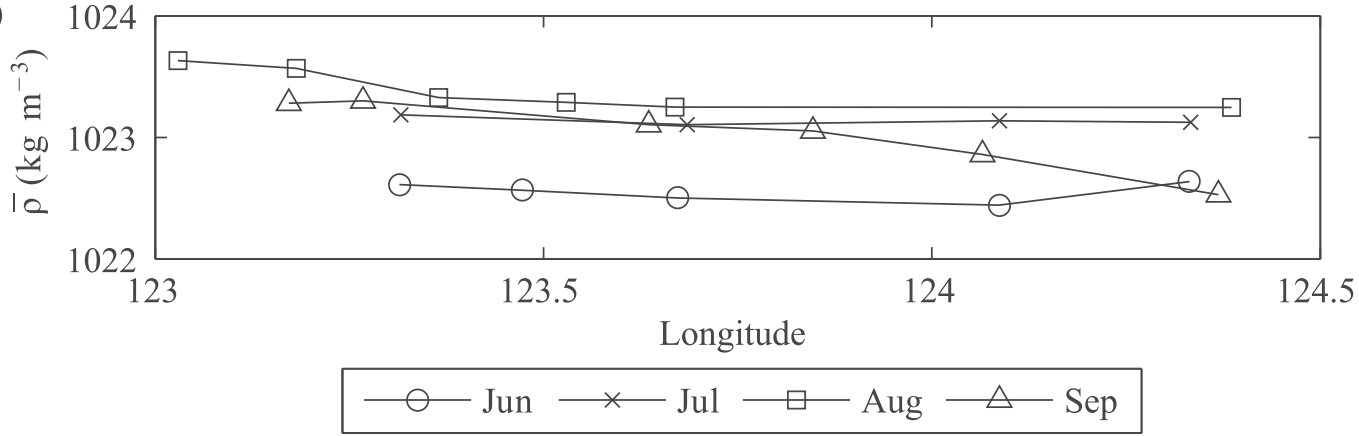

Fig. 4. Depth-averaged (a) temperature (b) salinity and (c) density for the cross-shore transects shown in Fig. 1.

concentrations occurred in the southern and coastal regions, south and east of Montgomery Reef (Fig. 8c). Chl- $a$ showed a distinct spatial shift at latitude $\sim 15.7^{\circ} \mathrm{S}$, corresponding with the location of the density front (see Fig. 8c), with total Chl- $a$ concentrations ranging from $0.6 \mu \mathrm{g} \mathrm{L}^{-1}$ to $1.0 \mu \mathrm{g} \mathrm{L}^{-1}$ and $0.1 \mu \mathrm{g} \mathrm{L}^{-1}$ to $0.4 \mu \mathrm{g} \mathrm{L}^{-1}$ south and north of the front, respectively. This distinct shift in chl- $a$ concentration was accompanied by a change in the contribution of small $(<5 \mu \mathrm{m})$ phytoplankton to total chl- $a$ biomass, with small phytoplankton contributing a lower proportion to total biomass south of the front (chl- $a<5 \mu \mathrm{m}=65-75 \%$ ) relative to the north (chl- $a<5 \mu \mathrm{m}=85-95 \%$ ) (Fig. 8d). Despite lower sampling resolution in the June survey compared with the August survey, we similarly observed that small phytoplankton accounted for the bulk of chl- $a$ biomass north of the density front.

In situ chl-a fluorescence profiles of the water column showed vertical structure throughout the study region (e.g., Figs. $5 \mathrm{c}$ and $6 \mathrm{~b}$ and d). A subsurface in situ chl- $a$ fluorescence maxima (at $\sim 30 \mathrm{~m}$ depth) was present in the cross-shore transect for June, July and August (a representative transect is shown for August survey in Fig. 5c). In June and August, the highest in situ chl- $a$ fluorescence occurred at the front location $\left(15.6^{\circ} \mathrm{S}\right.$ for the June survey (Figure $6 \mathrm{~b}$ ) and $15.7^{\circ} \mathrm{S}$ for August survey (Fig. $6 \mathrm{~d}$ )). To the north of the front, in situ chl- $a$ fluorescence was lowest at the surface with a subsurface maximum (Fig. 6b and d). To the south of the front, where the water column was well-mixed, the in situ chl- $a$ fluorescence was also relatively uniform with depth (Fig. $6 \mathrm{~b}$ and d).

\subsection{Picophytoplankton, bacteria and viruses}

In August, when small phytoplankton and microbial communities were investigated in further detail using flow cytometry, two picophytoplankton groups, Synechococcus and picoeukaryotes, were observed in the surface waters at all stations. Of these two groups, Synechococcus numerically dominated the picophytoplankton, ranging from $2.08 \times 10^{7}$ to $14.25 \times 10^{7}$ cells $\mathrm{L}^{-1}$ and contributed 3.20-21.95 $\mu \mathrm{g} \mathrm{C} \mathrm{L}{ }^{-1}$ to the planktonic carbon biomass (Table 2, Fig. 8e). Abundances of picoeukaryotes were $1-2$ orders of magnitude lower than Synechococcus, ranging between $0.12 \times 10^{7}$ and $0.64 \times 10^{7}$ cells L $^{-1}$ and accounting for $1.63-8.47 \mu \mathrm{g} \mathrm{C} \mathrm{L}^{-1}$ of the planktonic carbon biomass (Table 2, Fig. 8f). As was the case for the chl- $a<5 \mu \mathrm{m}$ fraction, distinct shifts in Synechococcus and picoeukaryotes occurred north and south of the density front in August. To the north of the front, Synechococcus and picoeukaryotes abundances were on average 2 times and 1.5 times higher, respectively, compared to the south. While picoeukaryotes exhibited a similar trend to Synechococcus, the picoeukaryote abundances were generally patchier over the study region, with a maximum occurring at the front location. Viral abundances varied 10 -fold across the study area, ranging from $5.72 \times 10^{7}$ to $146.8 \times 10^{7}$ cells L $^{-1}$. The highest abundances of viruses occurred in Camden Sound and close to the coast, with a distinct shift from low to relatively high concentrations south and north of the frontal region, respectively (Fig. 8g). On average, bacterial abundances were 4-fold higher than Synechococcus, ranging from $18.41 \times 10^{7}$ to $41.92 \times 10^{7}$ cells L $^{-1}$, and showed a similar trend to picophytoplankton with relatively higher abundances occurring north of the density front (Table 2, Fig. 8h).

The relationships between picophytoplankton, bacteria, viruses and measured physico-chemical and biological parameters from the August survey are summarised in Table 3. Synechococcus was positively correlated with picoeukaryotes $(r=0.48, p<0.001)$, bacteria $(r=0.70, p<0.001)$ and surface water temperature $(r=0.54, p<0.001)$ but negatively correlated with $\mathrm{NO}_{\mathrm{x}}(r=-0.63$, 
a)

b)
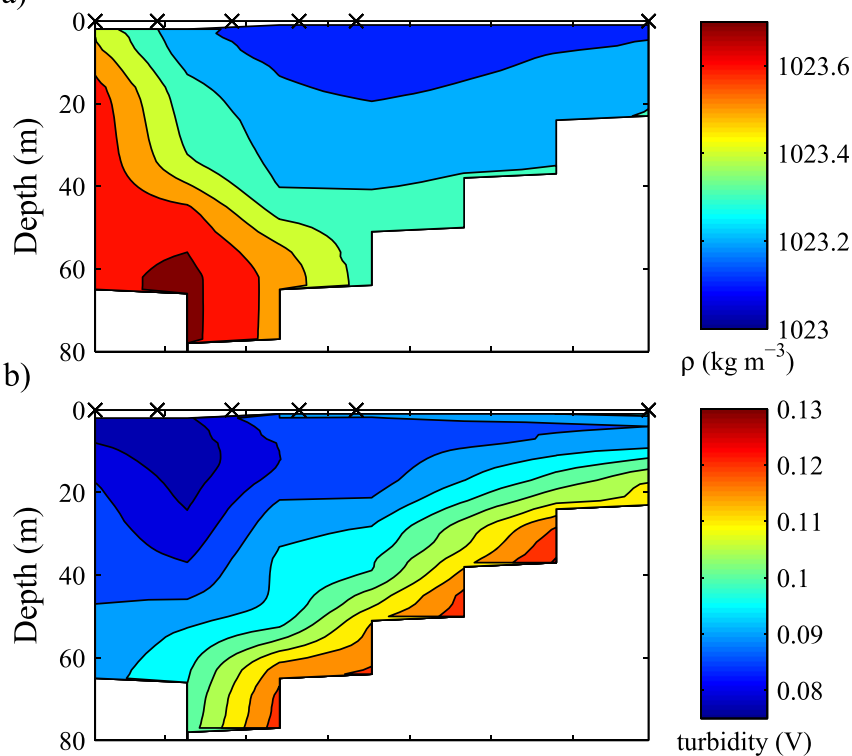

$\rho\left(\mathrm{kg} \mathrm{m}^{-3}\right)$

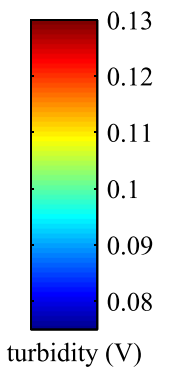

c)

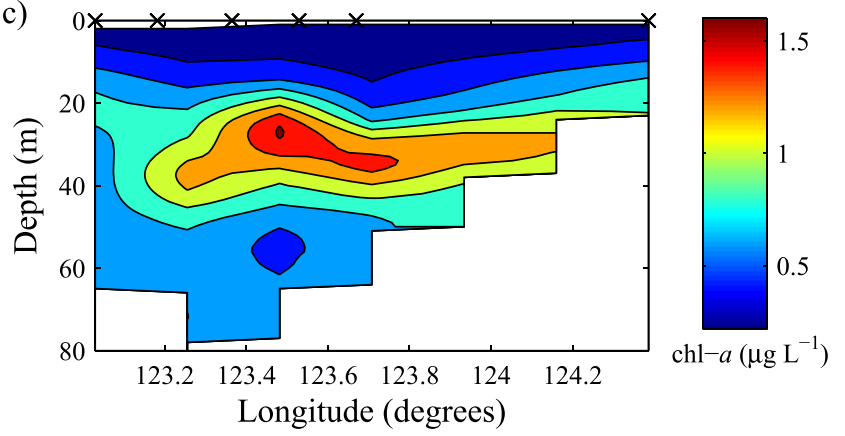

Fig. 5. (a) Density, (b) turbidity and (c) calibrated chl-a vertical profiles for the August cross-shore transect. The crosses indicate the CTD cast locations, which are also shown in Fig. 1.

$p<0.05)$. Similarly, picoeukaryotes were positively correlated with bacteria $(r=0.42, p<0.005)$, chl- $a<5 \mu \mathrm{m}(r=0.32, p<0.05)$ and in situ chl- $a$ fluorescence $(r=0.29, p<0.05)$, but were negatively correlated with salinity $(r=-0.34, p<0.05)$ and $\mathrm{NO}_{\mathrm{x}}(r=-0.62$, $p<0.05)$. Synechococcus, bacteria and viruses abundances all exhibited a decrease with increasing chl- $a$ (all $p<0.005$ ), in situ chl$a$ fluorescence (all $p<0.05$ ) and turbidity (all $p<0.05$ ). Viruses were positively correlated with Synechococcus $(r=0.34, p<0.05)$ and bacteria $(r=0.38, p<0.001)$.

\section{Discussion}

\subsection{Physical conditions}

Despite the extreme tidal range in the study region, most of it remained vertically stratified, except in the inshore region between Montgomery Reef and the mainland. Furthermore, the weak horizontal salinity gradients (with increased density offshore) persisted throughout the dry season (Fig. 2a). This suggests continuing but decreasing terrestrial freshwater inputs occurred during the dry season, despite negligible rainfall within the period.

Increased latent heat losses during episodic periods of southeasterly winds and low relative humidity led to rapid decreases in coastal water temperature. Differential cooling resulted in cooler inshore water temperatures from June to August, as a uniform surface heat flux loss will generate a greater decrease in temperature in shallow water than deep water (Monismith et al., 1990; Sturman et al., 1999). The cross-shore temperature and salinity gradients from June to August tended to counterbalance one another, resulting in a near-uniform cross-shore density field. In September, when the shallow coastal waters warmed faster than the offshore water, a stronger cross-shore density gradient formed. These gradients would likely support a buoyancy-driven flow that, though relatively weak, may still be important in driving crossshore exchange over seasonal timescales.

During this study, the highest turbidity occurred in Collier Bay, likely the result of this area receiving turbid water from a number of large central Kimberley catchments during the wet season that first accumulates and is then resuspended by the energetic tides. The importance of the transport of fine sediment from the southern Kimberley's Fitzroy River catchment into King Sound was described by Wolanski and Spagnol (2003). They showed fine sediment arrived and accumulated in King Sound during the wet season and was subsequently resuspended during energetic events during the dry season (Wolanski and Spagnol, 2003). A similar process is likely to occur in our study region. Larger sediment loads will be delivered to Collier Bay compared with Camden Sound due to the much larger catchment area that discharges into Collier Bay $\left(\sim 20,000 \mathrm{~km}^{2}\right.$ versus $\sim 500 \mathrm{~km}^{2}$ ). This larger sediment load, combined with the increased bed shear stresses and vertical velocities associated with both the flow constrictions and secondary circulations resulting from the complex morphology surrounding Collier Bay, likely led to the observed higher turbidity in the region adjacent to Montgomery Reef.

A density gradient was observed between the semi-enclosed embayment (Collier Bay) and the more open coastal ocean (Camden Sound), with a well-defined front separating these two distinct

\section{June Survey}
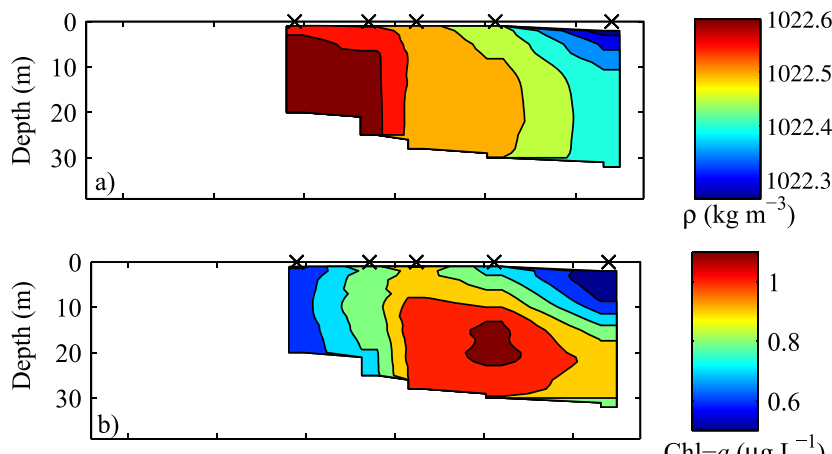

August Survey
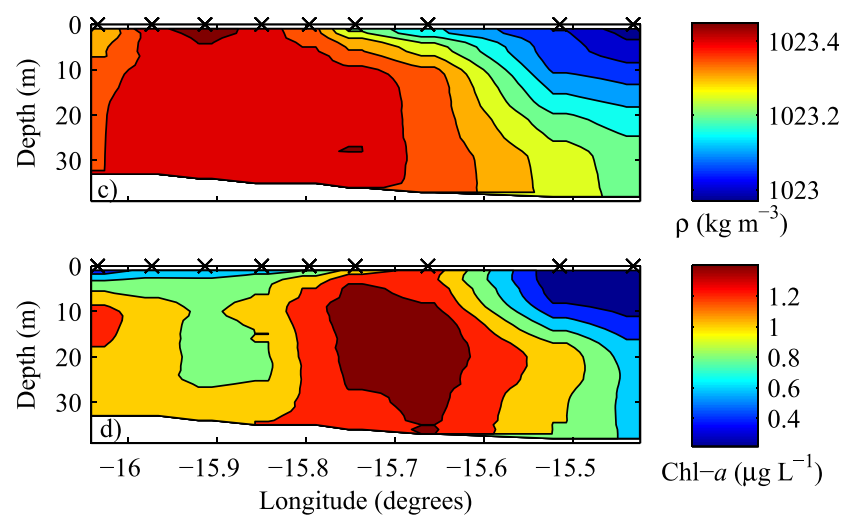

Fig. 6. (a) and (c) Density, (b) and (d) calibrated chl-a vertical profiles for the June (a and $b$ ) and August ( $c$ and d) along-shore transect. The crosses indicate the CTD cast locations, which are also shown in Fig. 1. 
Table 2

Summary of sea surface chl-a, dissolved nutrients, autotrophic picoplankton, bacteria and virus concentrations during the June and August surveys.

\begin{tabular}{|c|c|c|}
\hline Parameter & June & August \\
\hline \multicolumn{3}{|c|}{ Dissolved Nutrients $\left(\mu \mathrm{mol} \mathrm{L}^{-1}\right)$} \\
\hline $\mathrm{NO}_{\mathrm{x}}$ & $<0.14-0.57$ & $<0.14-0.50$ \\
\hline $\mathrm{NH}_{4}$ & $<0.21-1.60$ & $<0.21-1.36$ \\
\hline $\mathrm{PO}_{4}$ & $0.10-0.36(0.21)$ & $0.15-0.42(0.25)$ \\
\hline $\mathrm{Si}$ & $2.67-11.04(6.20)$ & $1.32-9.97(5.67)$ \\
\hline \multicolumn{3}{|l|}{ chl- $a$} \\
\hline Total $\left(\mu \mathrm{g} \mathrm{L}^{-1}\right)$ & $0.32-1.04(0.63)$ & $0.10-1.08(0.5)$ \\
\hline$>5 \mu \mathrm{m}\left(\mu \mathrm{g} \mathrm{L}^{-1}\right)$ & $0.02-0.17(0.08)$ & $0.005-0.33(0.09)$ \\
\hline$>5 \mu \mathrm{m}(\%)$ & $2.70-23.48(12.19)$ & $4.29-35.86(14.57)$ \\
\hline \multicolumn{3}{|c|}{ Cell abundance $\left(\times 10^{7}\right.$ cells $\left.\mathrm{L}^{-1}\right)$} \\
\hline Syn & NS & $2.08-14.25(7.96)$ \\
\hline Peuk & NS & $0.12-0.64(0.30)$ \\
\hline $\mathrm{Bac}$ & NS & $18.41-41.92(31.05)$ \\
\hline Virus & NS & $5.72-146.8(55.91)$ \\
\hline \multicolumn{3}{|c|}{ 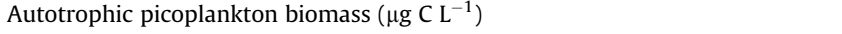 } \\
\hline Syns & NS & $3.20-21.95(12.26)$ \\
\hline Peuk & NS & $1.63--8.47(3.96)$ \\
\hline
\end{tabular}

Values represent minimum and maximum concentrations with mean values indicated in parentheses. Where dissolved nutrient concentrations were less than the detection limits of the instrument, no means are given. NS indicates that the parameter was not sampled at that time. Syn = Synechococcus; Peuk $=$ picoeukaryotes and $\mathrm{Bac}=$ bacteria.

coastal water masses. This front can be classified as a tidal mixing front, forming due to the enhanced vertical mixing overcoming the generation rate of buoyancy from freshwater input south of $15.7^{\circ} \mathrm{S}$ (e.g., Simpson and Hunter, 1974; O'Donnell, 1993, 2010). In the constricted location between Montgomery Reef and the mainland, large tidal velocities in excess of $1.5 \mathrm{~m} \mathrm{~s}^{-1}$ during spring tides resulted in the water column being comparatively vertically wellmixed (personal communication, Lei Tian). In the more open Camden Sound, on the other hand, the water column was stably stratified as the generation rate of buoyancy exceeded the rate of vertical mixing. The persistent alongshore density gradient due to the cooler water surrounding Montgomery Reef likely resulted in horizontal motions leading to the observed intrusion of the denser water towards the north at the seabed and less dense water towards the south near the surface (e.g., O'Donnell, 1993).

\subsection{Nutrient distributions}

To our knowledge, these are the first reported spatial measurements of surface nutrient concentrations in the coastal waters of the Kimberley. Surface waters in the Camden Sound/Collier Bay region were overall oligotrophic, with low (to undetectable) nitrogen concentrations (as $\mathrm{NO}_{\mathrm{x}}$ and $\mathrm{NH}_{4}$ ); typical of other tropical inshore locations during the dry season, e.g., the GBR system on the east coast of Australia that is at a similar latitude (Furnas et al., 2005; Schaffelke et al., 2012; McKinnon et al., 2013) and the tropical coastal waters of Java, Indonesia (Jennerjahn et al., 2004). However, at stations within and adjacent to Collier Bay, relatively higher concentrations of $\mathrm{NO}_{\mathrm{x}}$ were observed compared to the rest of the study region. This likely occurred due to the limited exchange of Collier Bay water with the surrounding ocean and increased vertical mixing in the topographically constricted locations that contrasts with surface $\mathrm{NO}_{\mathrm{x}}$ depletion in the vertically stratified regions. The $\mathrm{PO}_{4}$ concentrations were slightly higher than typical values observed in the inshore regions of the GBR in both dry and wet seasons (Furnas et al., 2005; McKinnon et al., 2013) and in coastal waters further south along the northwest coast of Australia (Furnas, 2007; Wyatt et al., 2012), but were similar to $\mathrm{PO}_{4}$ concentrations in the coastal waters of a macrotidal estuarine system in the Brazilian Amazonian basin (Pamplona et al., 2013).
The average molar ratio of surface inorganic nitrogen to phosphate (less than 3:1) in the Camden Sound/Collier Bay region in August was well below the Redfield ratio of 16:1, indicating a strong potential for nitrogen limitation of phytoplankton in the surface waters at this time. This raises the possibility that nitrogen limits phytoplankton biomass accumulation over this region. However, both nitrogen and phosphorus dynamics can be strongly impacted by sediment adsorption (Liang et al., 2013), especially across salinity gradients (Fitzsimons et al., 2006); our work highlights the importance of determining potential sources of nitrogen in the area, including loads associated with riverine sediment (Hou et al., 2003) and offshore nitrogen fixation (Waite et al., 2013). Ammonium adsorption to sediments, especially on fine clays, is strongly salinity-dependent, and the seasonal salinity dynamics documented here are also likely to impact these processes. Furthermore, dissolved organic nitrogen (DON) could be an additional nitrogen source in this DIN-depleted coastal system (e.g., Jennerjahn et al., 2004). Other studies have shown that DON is the dominant form of $\mathrm{N}$ in less-anthropogenically disturbed catchments (e.g., Burford et al., 2012). The significant microbial community identified during the August survey could play an important role in converting DON that cannot be directly utilised by phytoplankton to DIN (e.g., Jennerjahn et al., 2004).

The range of observed Si concentrations was similar to inshore observations on the GBR (Furnas et al., 2005; McKinnon et al., 2013) but significantly lower than the tropical coastal waters of Java, Indonesia (Jennerjahn et al., 2004). Si displayed a cross-shelf gradient with highest concentrations occurring close to the coast; reflecting the terrestrial source of this nutrient and the $\mathrm{Si}$ remineralisation processes occurring in the shallow coastal sediments (Alongi, 1989). We note that Si distributions are also potentially impacted by estuarine sediment dynamics, particularly in macrotidal areas where sediment resuspension is high, but less is known about this, and its effect has not been studied in the Kimberley to date (Tallberg et al., 2013).

\subsection{Phytoplankton and microbial distribution}

During the June and August surveys, the surface phytoplankton biomass (as chl- $a$ ) averaged $0.5 \mu \mathrm{g} \mathrm{L}^{-1}$, comparable to chl- $a$ biomass values reported by Thompson and Bonham (2011) at 50 m depth on the inner southern Kimberley shelf located $\sim 100 \mathrm{~km}$ south of the present study region during April and May 2010. Nevertheless, these values are higher than those typically recorded in coastal and shallow-shelf waters further south along the north-western Australian coast (Thompson et al., 2011). Phytoplankton $>2 \mu \mathrm{m}$ but $<15 \mu \mathrm{m}$ in size have been observed to dominate phytoplankton biomass on the Australian North West shelf $(\sim 750 \mathrm{~km}$ southwest of our study region) (Hallegraeff and Jeffrey, 1984); however, our results show that over the sampled region, small phytoplankton $(<5 \mu \mathrm{m})$, encompassing picophytoplankton and the smallest nanoplankton (where nanoplankton are defined as cells $2-20 \mu \mathrm{m}$ ), comprised on average $88 \%$ and $85 \%$ of the chl- $a$ biomass in both June and August, respectively (Table 2 and see Fig. $8 \mathrm{~b}$ and d). These $<5 \mu \mathrm{m}$ chl- $a$ values, are slightly higher than those of Thompson and Bonham (2011) (68\% of chl- $a$ in phytoplankton cells $<5 \mu \mathrm{m}$ for their inner-shelf Kimberley measurements) in April 2010, and confirm the dominance of small phytoplankton in the coastal waters of the Kimberley in the dry season.

Two distinct groups of picophytoplankton (cells $<2 \mu \mathrm{m}$ in size) were identified with flow cytometry in surface seawater samples from all stations in August: a group of prokaryotic cyanobacteria Synechococcus and a (likely) diverse group of picoeukaryotes. There are a limited number of direct counts of any picophytoplankton groups in Australian tropical waters; however, Synechococcus 


\section{June survey}
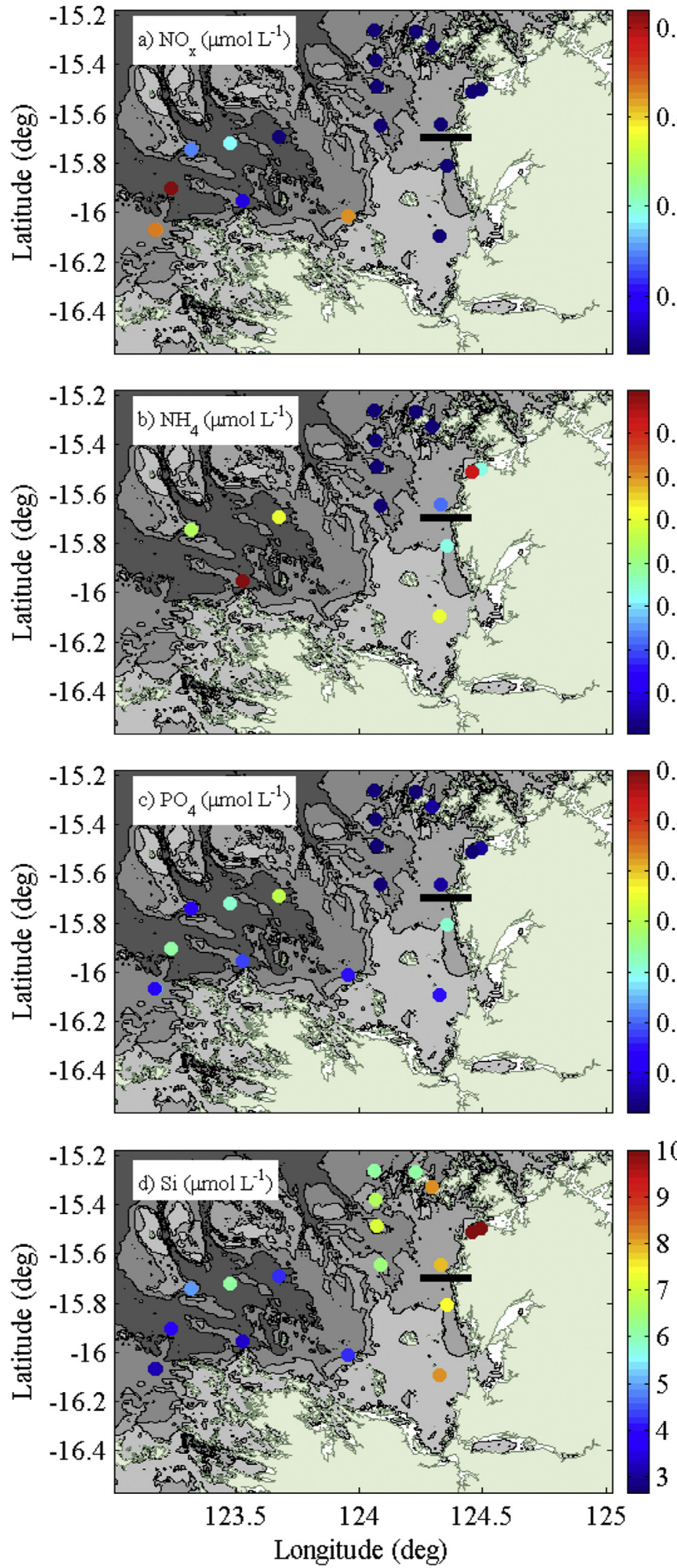

\section{August survey}
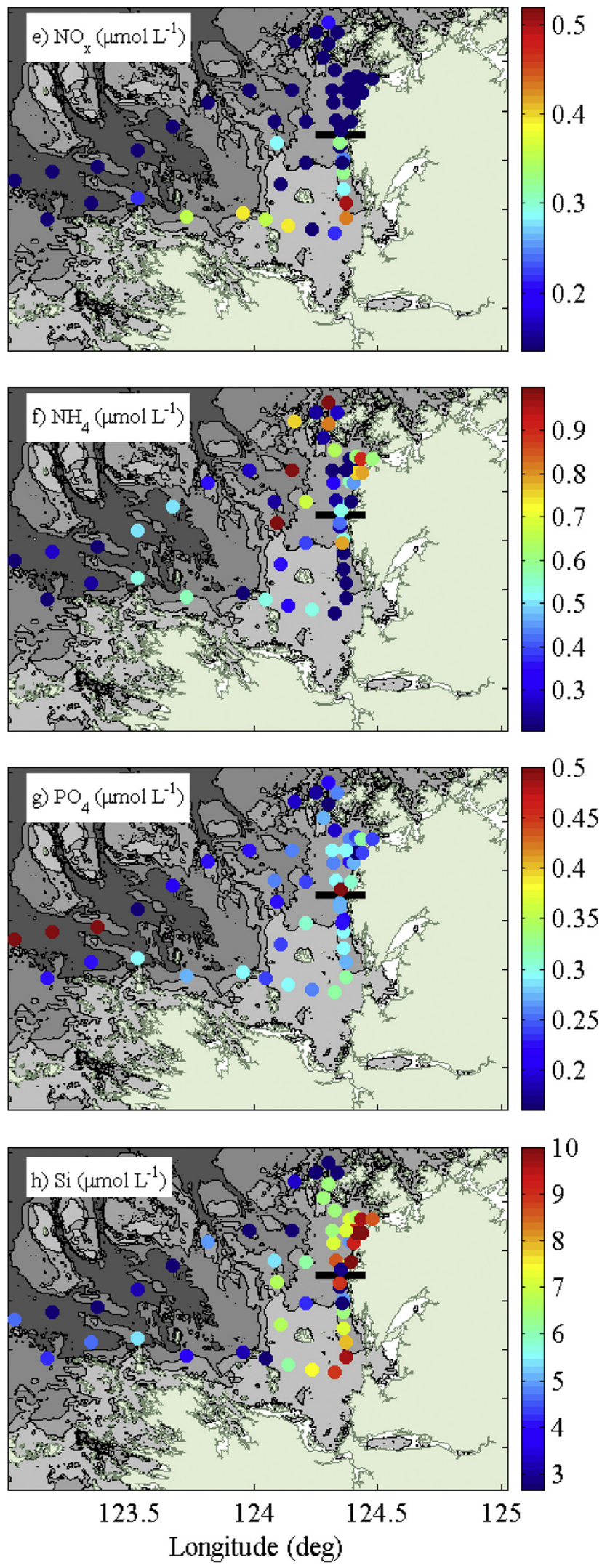

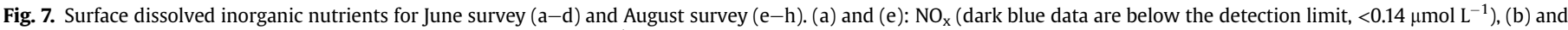

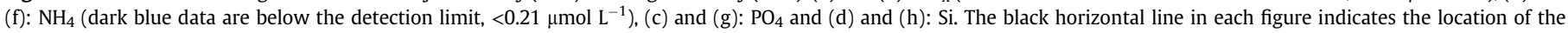
density front. (For interpretation of the references to colour in this figure legend, the reader is referred to the web version of this article.) 


\section{June survey}
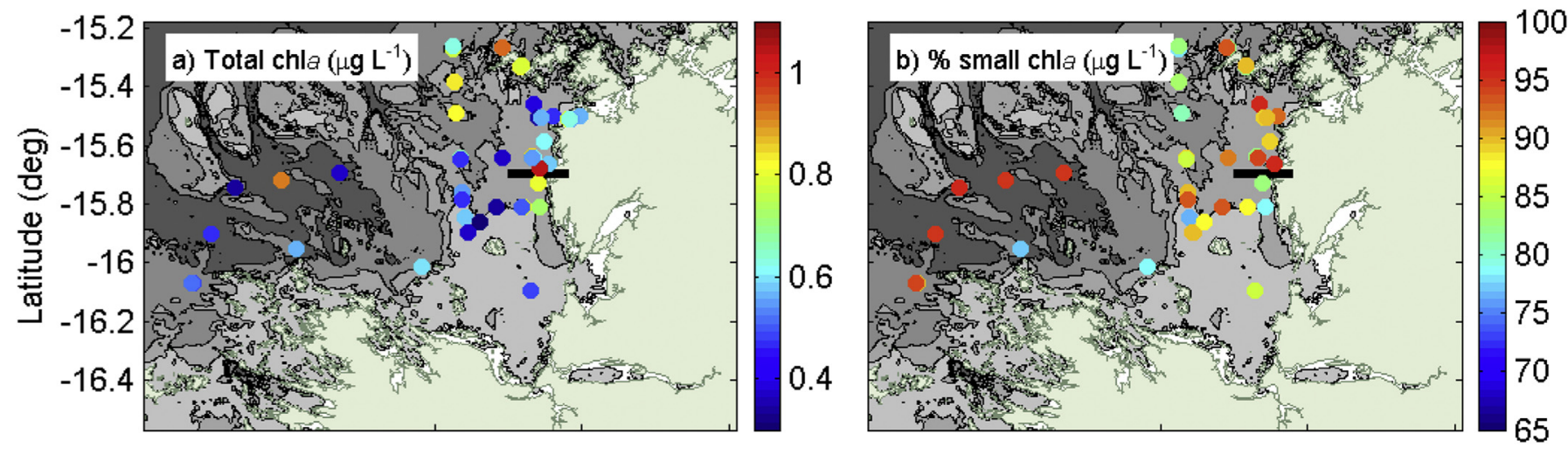

\section{August survey}
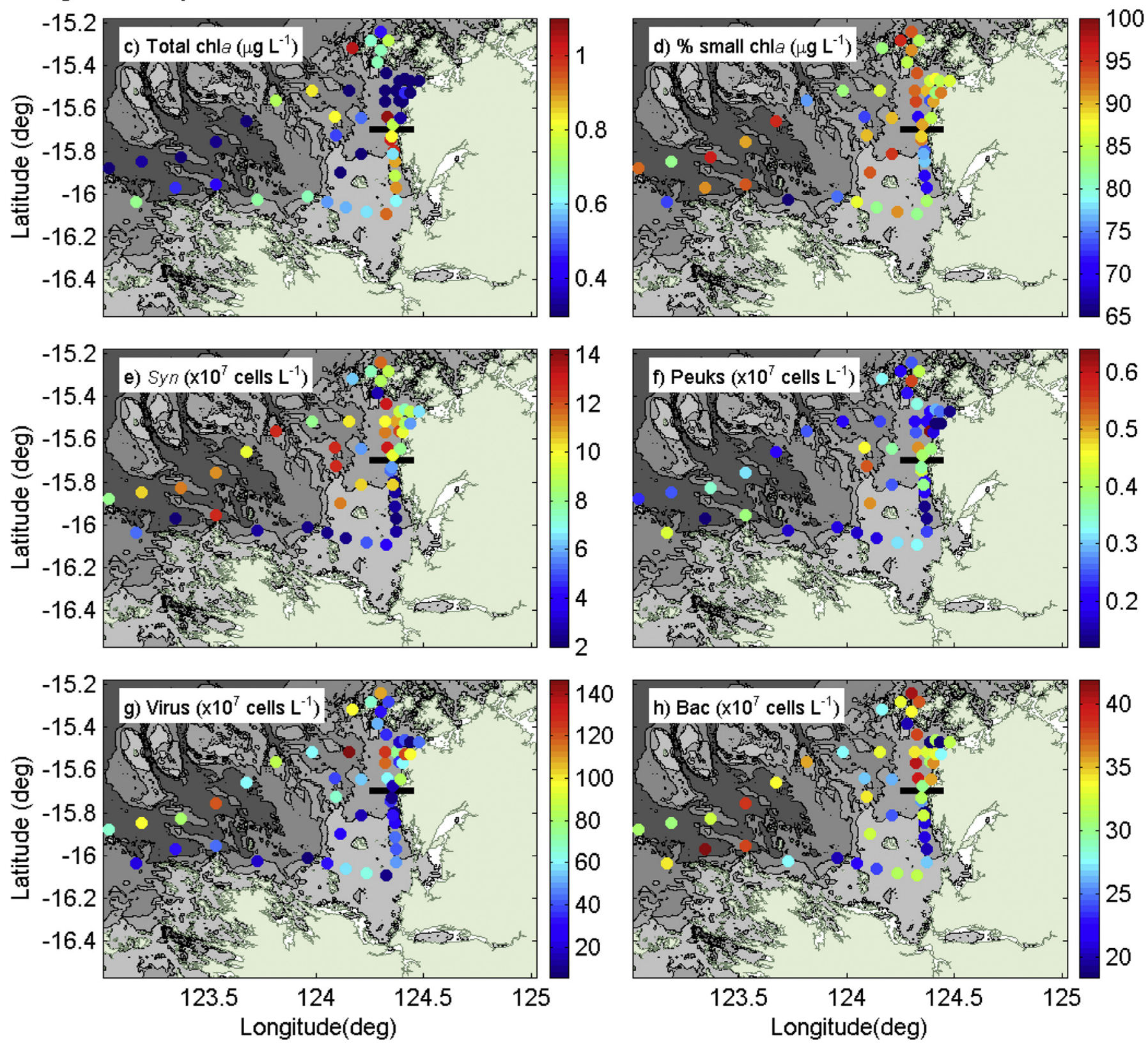

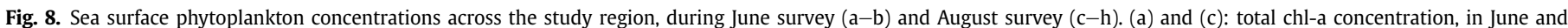

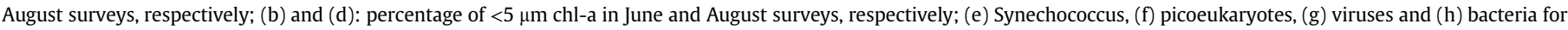
the August survey. 
Table 3

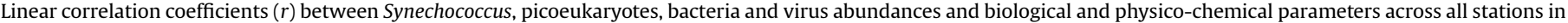
the during the August 2008 survey.

\begin{tabular}{|c|c|c|c|c|c|c|c|c|c|c|c|c|c|}
\hline & Peuk & $\mathrm{Bac}$ & Vir & chl- $a$ & chl- $a<5$ & Fluor & Turb & Temp & Sal & $\mathrm{NO}_{\mathrm{x}}$ & $\mathrm{NH}_{4}$ & $\mathrm{PO}_{4}$ & $\mathrm{Si}$ \\
\hline \multirow[t]{2}{*}{ Syn } & $0.48^{* * * *}$ & $0.70^{* * * *}$ & $0.34^{*}$ & $-0.38^{* *}$ & $-0.33^{*}$ & $-0.36^{*}$ & $-0.41^{* *}$ & $0.54^{* * *}$ & -0.15 & $-0.63^{*}$ & -0.07 & -0.184 & 0.07 \\
\hline & $\mathrm{N}=55$ & $\mathrm{~N}=53$ & $N=53$ & $N=55$ & $N=55$ & $N=55$ & $N=55$ & $N=55$ & $N=55$ & $N=14$ & $N=52$ & $N=49$ & $N=53$ \\
\hline \multirow[t]{2}{*}{ Peuk } & & $0.42^{* *}$ & -0.166 & 0.24 & $0.29 *$ & $0.32 *$ & 0.17 & 0.11 & $-0.34^{*}$ & $-0.62 *$ & 0.16 & -0.23 & -0.03 \\
\hline & & $N=53$ & $N=53$ & $N=55$ & $N=55$ & $N=55$ & $N=55$ & $N=55$ & $N=55$ & $N=14$ & $N=52$ & $N=49$ & $N=53$ \\
\hline \multirow[t]{2}{*}{ Bac } & & & $0.38^{* * *}$ & $-0.47^{* * *}$ & $-0.43^{* *}$ & $-0.42^{*}$ & $-0.27^{*}$ & 0.17 & -0.01 & $-0.72^{*}$ & -0.12 & -0.01 & 0.22 \\
\hline & & & $N=54$ & $N=54$ & $N=54$ & $N=54$ & $N=54$ & $N=54$ & $N=54$ & $N=13$ & $N=51$ & $N=48$ & $N=52$ \\
\hline \multirow[t]{2}{*}{ Virus } & & & & $-0.62^{* * *}$ & $-0.62^{* * *}$ & $-0.58^{* * *}$ & $-0.63^{* * *}$ & $0.32^{*}$ & -0.07 & 0.02 & -0.10 & 0.04 & 0.24 \\
\hline & & & & $N=54$ & $N=54$ & $N=54$ & $N=54$ & $N=45$ & $N=54$ & $N=13$ & $N=51$ & $N=48$ & $N=52$ \\
\hline
\end{tabular}

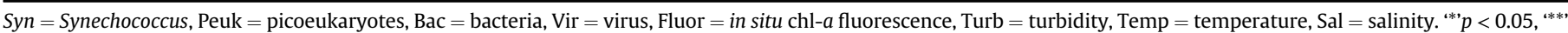
$p<0.005$, “***' $p<0.001$. Data log transformed.

concentrations were, on average, two to ten times higher than those occurring adjacent to Ningaloo Reef to the south in northwestern Australia $\left(22.23^{\circ} \mathrm{S}, 113.84^{\circ} \mathrm{E}\right.$ ) (Patten et al., 2011), but slightly lower than average values reported in central GBR waters at 20-40 m depth (Crosbie and Furnas, 2001). Our results, which are based on literature cell to carbon conversions, suggest Synechococcus comprised $49 \%$ of chl- $a$ biomass in Kimberley coastal waters. Thompson and Bonham (2011) similarly showed using HPLC, that Synechococcus dominated the chl- $a$ biomass in the April-May 2010 central Kimberley shelf observations, comprising $40 \%$ of the chl- $a$ biomass in a water column depth of $50 \mathrm{~m}$. These similarities suggest that Synechococcus is an important contributor to the phytoplankton community in Kimberley coastal waters in the dry season. Picoeukaryote concentrations in the Kimberley region during this dry season study were on the same order of magnitude as those occurring off Ningaloo Reef $(\sim 1300 \mathrm{~km}$ to the southwest) (Patten et al., 2011). Prochlorococcus, a group of picoplankton that should be detectable with flow cytometry if present, were absent from the surface coastal waters that were sampled in this study. Prochlorococcus contribute a large fraction to total chl- $a$ biomass in tropical offshore waters (Olson et al., 1990), including those waters at the 200 m depth contour off the Kimberley coast (Thompson and Bonham, 2011).

Given the dominance of small phytoplankton in the region during the June and August surveys, it was interesting that for the August survey, Synechococcus and picoeukaryotes did not correspond well with the total chl- $a$ biomass. One reason for this could be that phytoplankton $>2 \mu \mathrm{m}$ but $<5 \mu \mathrm{m}$ (i.e., small nanoplankton not enumerated with flow cytometry) contributed a high proportion of biomass to the chl- $a<5 \mu \mathrm{m}$ fraction. To determine if this was the case, the contribution of small nanoplankton to total chl- $a$ biomass was estimated by converting the total average picophytoplankton concentration (Synechococcus plus picoeukaryotes) to carbon biomass (see Section 2.2) (Buitenhuis et al., 2012). Secondly, we assumed a C:chl- $a$ ratio of 50 (Geider, 1987); thus based on average daily PAR at the surface of $1000 \mu \mathrm{mol}$ photons $\mathrm{m}^{-2} \mathrm{~s}^{-1}$ and a light attenuation coefficient $(k)$ of $\sim 0.1 \mathrm{~m}^{-1}$ (P. Thompson unpublished data), small nanoplankton $(2-5 \mu \mathrm{m})$ were estimated to account for only $\sim 21 \%$ of the $<5 \mu \mathrm{m}$ chl- $a$ biomass. This suggests that the weak correlation of both Synechococcus and picoeukaryotes with total chl- $a$ is more likely the result of other processes, such as the adsorption of phytoplankton (and other microorganisms) to suspended particles (see below), and/or spatial variation in the carbon biomass of individual picoplankton cells/groups (Buitenhuis et al., 2012).

The lowest counts of Synechococcus, bacteria and viruses occurred when surface waters were most turbid. At these times, light attenuation may limit Synechococcus production and subsequent bacterial assimilation of Synechococcus-derived photosynthetic exudates, resulting in lower Synechococcus and/or bacterial specific viruses. Alternatively, adsorption of nano- and pico-sized plankton cells and/ or their nutrient sources onto particles may be an important mechanism operating in the Kimberley coastal waters. Sediment particles in King Sound, in the southern part of the Kimberley but with similar water depths to our study area, were indeed shown to be bound together by organic matter, with these 'flocs' embedded with larger sized phytoplankton (e.g., diatoms, dinoflagellates and ciliates) and faecal pellets (Wolanski and Spagnol, 2003). Indirect scavenging and/or aggregation of planktonic organisms (including picoplankton, bacteria and viruses) onto a range of particle types is well documented in systems with high particle loads (e.g., lakes, estuaries) but also across a range of systems from coastal to oceanic (Simon et al., 2002; Turner, 2002; Weinbauer et al., 2009). The in situ particle structure is known to have a strong impact on nutrient adsorption and bacterial processing of suspended materials (e.g., Chang et al., 2003), though again, nothing is known of the rates and/ or importance of such processes in the Kimberley.

In August, Synechococcus and picoeukaryote concentrations covaried, with both groups exhibiting negative correlations with $\mathrm{NO}_{\mathrm{x}}$. These results may suggest picophytoplankton in the Kimberley have similar nutrient requirements, as demonstrated in other regions (Worden et al., 2004). However, given the overall low to below detection limit concentrations of $\mathrm{NO}_{\mathrm{x}}$ in surface waters (this study) and that not all Synechococcus isolates can assimilate nitrate (Moore et al., 2002; Scanlan et al., 2009), we are cautious to speculate further on key nutrient sources and assimilation processes for different picophytoplankton groups in the Kimberley. Close coupling of picophytoplankton and bacteria, as found here, occurs widely in oligotrophic marine systems, where bacteria take up a significant fraction of the dissolved organic nutrients produced by phytoplankton and subsequently play fundamental roles in the remineralisation, cycling and fate of organic matter through food webs (Azam et al., 1983). The positive relationship between viruses and bacteria, and viruses and Synechococcus, further suggests that viruses are important agents of picoplankton mortality. Viral induced mortality of bacteria, for example, can equal or exceed grazing mortality rates (e.g., Fuhrman and Noble, 1995), while an estimated 5-14\% loss of Synechococcus cells could occur through viral infection (Suttle and Chan, 1994). Following viral infection and lysis, picoplankton cellular products are released into surrounding waters and are rapidly assimilated by bacteria in an essentially semi-closed system (Middelboe et al., 2003); as much as one quarter of photosynthetically fixed organic carbon may short circuit back through the microbial food web (Wilhelm and Suttle, 1999). Alternatively, other mechanisms such as particle scavenging (as discussed above) and grazing of picoplankton by nanoplankton (Christaki et al., 2001) may act similarly to shape the distributions of the picoplankton community.

The vertically-stratified water column led to the formation of a sub-surface in situ chl-a fluorescence maximum in Camden Sound (e.g., Fig. 5). While photoinihibition of phytoplankton in surface waters may have led to the sub-surface in situ chl- $a$ fluorescence maximum at $\sim 30 \mathrm{~m}$, we suggest that the combined effects of the 
low surface nutrient concentrations and limited light below $\sim 50 \mathrm{~m}$ more likely resulted in the increased phytoplankton biomass near the pycnocline; a function of passive accumulation of cells, behavioural aggregation of cells (i.e., dinoflagellates) and/or higher amounts of chl- $a$ per unit biomass with decreasing irradiance (see Cullen, 1982). This is supported by the few historical $\mathrm{NO}_{\mathrm{x}}$ profiles from the inner-shelf of the Kimberley, which show sharp increases in nitrate concentration below the pycnocline (see Fig. 4 in Cresswell and Badcock, 2000).

\subsection{Water mass dynamics in the Camden Sound/Collier Bay region}

The presence of multiple islands, reefs and estuaries in our study region led to the creation of a number of different water masses with different physical, chemical and biological characteristics. The most distinct water masses were the well-mixed water between Montgomery Reef and the mainland and the density-stratified water of Camden Sound further to the north; a density front divided these water masses. The front was located at approximately the same location during both the June and August surveys, indicating it was likely a persistent feature during this time of the year.

The water masses to the north and south of this density front had distinctly different biogeochemical signatures. In the surface water, relatively high chl- $a$ biomass occurred at the location of the front (Fig. 6b and d). It is well-accepted that frontal regions are often characterised by high phytoplankton biomass, due to either in situ production in the front or convergent transport toward the front (Franks, 1992a,b; Fu et al., 2009; Riemann et al., 2011). Phytoplankton biomass in the frontal region was most likely stimulated by the supply of nutrients (particularly nitrogen) from the vertically well-mixed water (Fig. 7e) into surface waters on the nutrient-depleted stratified side of the front (Franks, 1992a). The shift towards a higher proportion of smaller size phytoplankton north of the front follows the predicted community structure for tidal fronts, where the water on the stratified side of the front has a higher proportion of small size phytoplankton (e.g., Franks, 1992a; Uye et al., 1999; Li et al., 2007). Despite relatively higher nitrogen concentrations in the well-mixed region (Fig. 7e), the overall chl- $a$ biomass was lower here than in the frontal region (Fig. $6 \mathrm{~b}$ and $\mathrm{d}$ ), possibly due to the higher turbidity, and hence lower light availability to stimulate production within this area (e.g., Cloern, 1987).

Across the density front, we also observed clear differences in the concentration of surface $\mathrm{NO}_{\mathrm{x}}$ and $\mathrm{NH}_{4}$, the proportion of small $(<5 \mu \mathrm{m})$ and large $(>5 \mu \mathrm{m})$ phytoplankton and the abundances of picophytoplankton, bacteria and viruses. These spatial shifts in phytoplankton biomass and phytoplankton and microbial community composition across a persistent density front (i.e., over a period of months), are likely to have consequences on planktonic food web function. However, to elucidate food web trophodynamics any further, sampling of the plankton community (microbes through to zooplankton) is required.

\section{Conclusions and future directions}

For the first time, this study captured the spatial and intraseasonal variation in the physico-chemical and biological regime throughout a dry season in the coastal waters of the Kimberley. The morphologically-complex central Kimberley coast led to the partial isolation of some of the study region, creating distinct water masses within a relatively small area. These spatial variations in physical conditions, in turn, impacted the spatial distribution of dissolved nutrients, and subsequent chl- $a$ and picophytoplankton biomass and microbial community structure.

To further understand both the trophic and microbial food web dynamics in Kimberley coastal waters, higher horizontal spatial resolution measurements of both nutrients and picoplankton are required in future studies. Furthermore, the role of particulatebound nutrients, DON and microbes may be important to biogeochemical cycling in this system, but these have yet to be measured. Finally, wet-season dynamics could be very different from the dryseason conditions presented here. Burford et al., (2012) found little seasonal variation in the nutrient concentrations in an Australian tropical monsoon estuary; however, studies at other tropical coastal regions have shown large seasonal variation, e.g., Pamplona et al., (2013). During the wet-season we expect much stronger cross-shore density stratification from fresh water inputs, and possibly high terrestrially-derived nutrient loads associated with the fresh water, which could dramatically alter the planktonic ecological response and thus warrants further investigation.

\section{Acknowledgements}

Thanks to the crew of the Kimberley Quest and Browse Express for assistance with the field experiments. We thank Y. Hetzel, S. Blake, M. Meuleners, and H. Van Haren for assistance in the field. We also thank E. Millar for assisting with processing some of the physical data. We are grateful to the Western Australian Marine Science Institute (WAMSI) for providing ship time aboard the Kimberley Quest and Browse Express. Support for the analysis of the data was provided by WAMSI projects 2.2.1, 2.2.2 and 2.2.6. NCEP Reanalysis data provided by the NOAA/OAR/ESRL PSD, Boulder, Colorado, USA, from their Web site at http://www.esrl. noaa.gov/psd/.

\section{References}

Alongi, D.M., 1989. Benthic processes across mixed terrigenous-carbonate sedimentary facies on the central Great Barrier Reef continental shelf. Cont. Shelf Res. 9 (7), 629-663.

Alongi, D.M., McKinnon, A.D., 2005. The cycling and fate of terrestrially-derived sediments and nutrients in the coastal zone of the Great Barrier Reef shelf. Mar. Pollut. Bull. 51 (1-4), 239-252.

Andutta, F.P., Ridd, P.V., Wolanski, E., 2013. The age and the flushing time of the Great Barrier Reef waters. Cont. Shelf Res. 53 (0), 11-19.

Anon, 1972. Australia Pilot. In: North, North- West, and West Coasts of Australia from the West Entrance of Endeavour Strait to Cape Leeuwin, sixth ed., vol. 5 (Hydrographer of the Navy).

Azam, F., Fenchel, T., Field, J., Gray, J., Meyer-Reil, L., Thingstad, F., 1983. The ecological role of water-column microbes in the sea. Mar. Ecol. -Prog. Ser. 10 (3), 257-263.

Brinkman, R., Wolanski, E., Deleersnijder, E., McAllister, F., Skirving, W., 2002. Oceanic inflow from the coral sea into the great barrier reef. Estuar. Coast. Shelf S. 54 (4), 655-668.

Brussaard, C.P.D., 2004. Optimization of procedures for counting viruses by flow cytometry. Appl. Environ. Microbiol. 70, 1506-1513.

Buitenhuis, E.T., et al., 2012. Picophytoplankton biomass distribution in the global ocean. Earth Syst. Sci. Data 5, 221-242.

Burford, M.A., Webster, I.T., Revill, A.T., Kenyon, R.A., Whittle, M., Curwen, G., 2012. Controls on phytoplankton productivity in a wet-dry tropical estuary. Estuar. Coast. Shelf S. $113(0), 141-151$.

Chang, F.H., Zeldis, J., Gall, M., Hall, J., 2003. Seasonal and spatial variation of phytoplankton assemblages, biomass and cell size from spring to summer across the north-eastern New Zealand continental shelf. J. Plankton Res. 25 (7), 737-758.

Christaki, U., Giannakourou, A., Van Wambeke, F., Grégori, G., 2001. Nanoflagellate predation on auto-and heterotrophic picoplankton in the oligotrophic Mediterranean Sea. J. Plankton Res. 23 (11), 1297-1310.

Cloern, J.E., 1987. Turbidity as a control on phytoplankton biomass and productivity in estuaries. Cont. Shelf Res. 7 (11-1), 1367-1381.

Cresswell, G., Badcock, K.A., 2000. Tidal mixing near the Kimberley coast of NW Australia. Mar. Freshw. Res. 51, 641-646.

Crosbie, N.D., Furnas, M.J., 2001. Abundance, distribution and flow-cytometric characterization of picophytoprokaryote populations in central $\left(17^{\circ} \mathrm{S}\right)$ and southern $\left(20^{\circ} \mathrm{S}\right)$ shelf waters of the Great Barrier Reef. J. Plankton Res. 23, 809-828.

Cullen, J.J., 1982. The deep chlorophyll maximum: comparing vertical profiles of chlorophyll a. Can. J. Fish. Aquat. Sci. 39 (5), 791-803.

Drupp, P., De Carlo, E.H., Mackenzie, F.T., Bienfang, P., Sabine, C.L., 2011. Nutrient inputs, phytoplankton response, and $\mathrm{CO}_{2}$ variations in a semi-enclosed subtropical embayment, Kaneohe Bay, Hawaii. Aquat. Geochem. 17 (4-5), 473-498. 
Fairall, C.W., Bradley, E.F., Rogers, D.P., Edson, J.B., Young, G.S., 1996. Bulk parameterization of air-sea fluxes for tropical ocean global atmosphere coupled ocean atmosphere response experiment. J. Geophys. Res.-Oceans 101 (C2), 3747-3764.

Fitzsimons, M.F., Millward, G.E., Revitt, D.M., Dawit, M.D., 2006. Desorption kinetics of ammonium and methylamines from estuarine sediments: consequences for the cycling of nitrogen. Mar. Chem. 101 (1-2), 12-26.

Franks, P.J.S., 1992a. Phytoplankton blooms at fronts: patterns, scales, and physical forcing mechanisms. Rev. Aquat. Sci. 6 (2), 121-137.

Franks, P.J.S., 1992b. Sink or swim, accumulation of biomass at fronts. Mar. Ecol. -Prog. Ser. 82, 1-12.

Fu, M., Wang, Z., Li, Y., Li, R., Sun, P., Wei, X., Lin, X., Guo, J., 2009. Phytoplankton biomass size structure and its regulation in the Southern Yellow Sea (China): seasonal variability. Cont. Shelf Res. 29 (18), 2178-2194.

Fuhrman, J.A., 1992. Bacterioplankton Roles in Cycling of Organic Matter: the Microbial Food Web, Primary Productivity and Biogeochemical Cycles in the Sea. Plenum Press, New York, pp. 361-383.

Fuhrman, J.A., Noble, R.T., 1995. Viruses and protists cause similar bacterial mortality in coastal seawater. Limnol. Oceanogr. 40 (7), 1236-1242.

Fung, I.Y., Harrison, D.E., Lacis, A.A., 1984. On the variability of the net longwave radiation at the ocean surface. Rev. Geophys. 22 (2), 177-193.

Furnas, M., 2007. Intra-seasonal and inter-annual variations in phytoplankton biomass, primary production and bacterial production at North West Cape Western Australia: links to the 1997-1998 El Niño event. Cont. Shelf Res. 27 (7), 958-980.

Furnas, M., Mitchell, A., Skuza, M., Brodie, J., 2005. In the other 90\%: phytoplankton responses to enhanced nutrient availability in the Great Barrier Reef Lagoon. Mar. Pollut. Bull. 51 (1-4), 253-265.

Geider, R.J., 1987. Light and temperature dependence of the carbon to chlorophyll a ratio in microalgae and cyanobacteria: implications for physiology and growth of phytoplankton. New. Phytol., 1-34.

Hallegraeff, G.M., Jeffrey, S.W., 1984. Tropical phytoplankton species and pigments of continental shelf waters of North and North-West Australia. Mar. Ecol. -Prog. Ser. 20, 59-74.

Hou, L.J., Liu, M., Jiang, H.Y., Xu, S.Y., Ou, D.N., Liu, Q.M., Zhang, B.L., 2003. Ammonium adsorption by tidal flat surface sediments from the Yangtze estuary. Environ. Geol. 45 (1), 72-78.

Jennerjahn, T.C., Ittekkot, V., Klöpper, S., Adi, S., Purwo Nugroho, S., Sudiana, N., Yusmal, A., Gaye-Haake, B., 2004. Biogeochemistry of a tropical river affected by human activities in its catchment: Brantas River estuary and coastal waters of Madura Strait, Java, Indonesia. Estuar. Coast. Shelf S. 60 (3), 503-514.

Johnston, D.W., Read, A.J., 2007. Flow-field observations of a tidally driven island wake used by marine mammals in the Bay of Fundy, Canada. Fish. Oceanogr. 16 (5), 422-435.

Kalnay, E., Kanamitsu, M., Kistler, R., Collins, W., Deaven, D., Gandin, L., Iredell, M., Saha, S., White, G., Woollen, J., 1996. The NCEP/NCAR 40-year reanalysis project. Bull. Am. Meteorol. Soc. 77 (3), 437-471.

Li, H.-B., TianXiao, Lv, R.-H., Ding, T., Lin, Y.-a., 2007. Impact of tidal front on the distribution of bacterioplankton in the southern Yellow Sea, China. J. Mar. Syst. 67 (3-4), 263-271.

Liang, D.F., Wang, X.L., Bockelmann-Evans, B.N., Falconer, R.A., 2013. Study on nutrient distribution and interaction with sediments in a macro-tidal estuary. Adv. Water Resour. 52, 207-220.

Marie, D., Brussaard, C.P.D., Thyrhaug, R., Bratbak, G., Vaulot, D., 1999. Enumeration of marine viruses in culture and natural samples by flow cytometry. Appl Environ. Microbiol. 65 (1), 45-52.

Masini, R.J., Sim, C.B., Simpson, C.J., 2009. Protecting the Kimberley: a synthesis of scientific knowledge to support conservation management in the Kimberley region of Western Australia. In: W. A. (Ed.), Part a: Marine Environments. Department of Environment and Conservation, Western Australia.

McKinnon, A.D., Logan, M., Castine, S.A., Duggan, S., 2013. Pelagic metabolism in the waters of the Great Barrier Reef. Limnol. Oceanogr. 58 (4), 1227-1242.

Middelboe, M., Riemann, L., Steward, G.F., Hansen, V., Nybroe, O., 2003. Virusinduced transfer of organic carbon between marine bacteria in a model community. Aquat. Microb. Ecol. 33 (1), 1-10.

Monismith, S.G., Imberger, J., Morison, M.L., 1990. Convective motions in the sidearm of a small reservoir. Limnol. Oceanogr. 35 (8), 1676-1702.

Moore, L.R., Post, A.F., Rocap, G., Chisholm, S.W., 2002. Utilization of different nitrogen sources by the marine cyanobacteria Prochlorococcus and Synechococcus. Limnol. Oceanogr., 989-996.

O'Donnell, J., 1993. Surface fronts in estuaries: a review. Estuar.Coasts 16 (1), 12-39.
O'Donnell, J., 2010. The dynamics of estuary plumes and fronts. In: Valle-Levinson, A (Ed.), Contemporary Issues in Estuarine Physics. Cambridge University Press.

Olson, R.J., Chisholm, S.W., Zettler, E.R., Altabet, M.A., Dusenberry, J.A., 1990. Spatial and temporal distributions of prochlorophyte picoplankton in the North Atlantic Ocean, deep sea research part A. Oceanogr. Res. Pap. 37 (6), 1033-1051.

Pamplona, F.C., Paes, E.T., Nepomuceno, A., 2013. Nutrient fluctuations in the Quatipuru river: a macrotidal estuarine mangrove system in the Brazilian Amazonian basin. Estuar. Coast. Shelf S. 133 (0), 273-284.

Patten, N.L., Wyatt, A.S.J., Lowe, R.J., Waite, A.M., 2011. Uptake of picophytoplankton, bacterioplankton and virioplankton by a fringing coral reef community (Ningaloo Reef, Australia). Coral Reefs 30 (3), 555-567.

Riemann, L., Nielsen, T.G., Kragh, T., Richardson, K., Parner, H., Jakobsen, H.H. Munk, P., 2011. Distribution and production of plankton communities in the subtropical convergence zone of the Sargasso Sea. I. Phytoplankton and bacterioplankton. Mar. Ecol. -Prog. Ser. 426, 57-70.

Rodríguez, F., Fernández, E., Head, R.N., Harbour, D.S., Bratbak, G., Heldal, M., Harris, R.P., 2000. Temporal variability of viruses, bacteria, phytoplankton and zooplankton in the western English Channel off Plymouth. J. Mar. Biol. Assoc. U. K. 80 (04), 575-586.

Ryther, J.H., 1969. Photosynthesis and fish production in the sea. Science 166 (3901), $72-76$.

Scanlan, D.J., Ostrowski, M., Mazard, S., Dufresne, A., Garczarek, L., Hess, W.R., Post, A.F., Hagemann, M., Paulsen, I., Partensky, F., 2009. Ecological genomics of marine picocyanobacteria. Microbiol. Mol. Biol. Rev. 73 (2), 249-299.

Schaffelke, B., Carleton, J., Skuza, M., Zagorskis, I., Furnas, M.J., 2012. Water quality in the inshore Great Barrier Reef lagoon: implications for long-term monitoring and management. Mar. Pollut. Bull. 65 (4), 249-260.

Simon, M., Grossart, H.-P., Schweitzer, B., Ploug, H., 2002. Microbial ecology of organic aggregates in aquatic ecosystems. Aquat. Microb. Ecol. 28 (2), 175-211.

Simpson, J.H., Hunter, J.R., 1974. Fronts in Irish sea. Nature 250 (5465), 404-406.

Sturman, J.J., Oldham, C.E., Ivey, G.N., 1999. Steady convective exchange flows down slopes. Aquat. Sci. 61 (3), 260-278.

Suttle, C.A., Chan, A.M., 1994. Dynamics and distribution of cyanophages and their effect on marine Synechococcus spp. Appl. Environ. Microbiol. 60 (9), 3167-3174.

Tallberg, P., Lehtoranta, J., Hietanen, S., 2013. Silicate release from sand-manipulated sediment cores: biogenic or adsorbed Si? Silicon 5 (1), 67-74.

Thompson, P.A., Bonham, P., 2011. New insights into the Kimberley phytoplankton and their ecology. J. R. Soc. West. Aust. 94 (2), 161-169.

Thompson, P.A., Bonham, P., Waite, A.M., Clementson, L.A., Cherukuru, N., Hassler, C., Doblin, M.A., 2011. Contrasting oceanographic conditions and phytoplankton communities on the east and west coasts of Australia. Deep-Sea Res. Pt. II 58 (5), 645-663.

Tomczak, M., Godfrey, J.S., 2003. Regional Oceanography: an Introduction, second ed. Daya Books.

Turner, J.T., 2002. Zooplankton fecal pellets, marine snow and sinking phytoplankton blooms. Aquat. Microb. Ecol. 27 (1), 57-102.

Uye, S., Iwamoto, N., Ueda, T., Tamaki, H., Nakahira, K., 1999. Geographical variations in the trophic structure of the plankton community along a eutrophic-mesotrophic-oligotrophic transect. Fish. Oceanogr. 8 (3), 227-237.

Waite, A.M., Rossi, V., Roughan, M., Tilbrook, B., Akl, J., Thompson, P.A., Feng, M., Wyatt, A.S.J., Raes, E.J., 2013. Formation and maintenance of high-nitrate, low $\mathrm{pH}$ layers in the Eastern Indian Ocean and the role of nitrogen fixation. Biogeosci. Discuss. 10 (3), 3951-3976.

Weinbauer, M., Bettarel, Y., Cattaneo, R., Luef, B., Maier, C. Motegi, C., Peduzzi, P. Mari, X., 2009. Viral ecology of organic and inorganic particles in aquatic systems: avenues for further research. Aquat. Microb. Ecol. 57 (3), 321.

Wilhelm, S.W., Suttle, C.A., 1999. Viruses and nutrient cycles in the sea. Bioscience 49 (10), 781-788.

Wolanski, E., Spagnol, S., 2000. Sticky waters in the great barrier reef. Estuar. Coast. Shelf S. 50 (1), 27-32.

Wolanski, E., Spagnol, S., 2003. Dynamics of the turbidity maximum in King Sound, tropical Western Australia. Estuar. Coast. Shelf S. 56 (5-6), 877-890.

Worden, A.Z., Nolan, J.K., Palenik, B., 2004. Assessing the dynamics and ecology of marine picophytoplankton: the importance of the eukaryotic component. Limnol. Oceanogr. 49, 168-179.

Wyatt, A.S.J., Falter, J.L., Lowe, R.J., Humphries, S., Waite, A.M., 2012. Oceanographic forcing of nutrient uptake and release over a fringing coral reef. Limnol. Oceanogr. 57 (2), 401-419. 